Discussion Paper No. 11-023

\title{
Dips and Floors in Workplace Training: Using Personnel Records to Estimate Gender Differences
}

Bernd Fitzenberger and Grit Muehler

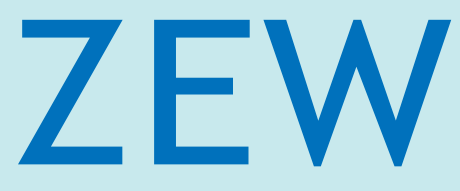

Zentrum für Europäische Wirtschaftsforschung $\mathrm{GmbH}$

Centre for European

Economic Research 
Discussion Paper No. 11-023

\section{Dips and Floors in Workplace Training: Using Personnel Records to Estimate Gender Differences}

Bernd Fitzenberger and Grit Muehler

Download this ZEW Discussion Paper from our ftp server:

ftp://ftp.zew.de/pub/zew-docs/dp/dp11023.pdf

Die Discussion Papers dienen einer möglichst schnellen Verbreitung von neueren Forschungsarbeiten des ZEW. Die Beiträge liegen in alleiniger Verantwortung der Autoren und stellen nicht notwendigerweise die Meinung des ZEW dar.

Discussion Papers are intended to make results of ZEW research promptly available to other economists in order to encourage discussion and suggestions for revisions. The authors are solely responsible for the contents which do not necessarily represent the opinion of the ZEW. 


\section{Non-technical summary}

Life-long learning is considered necessary to sustain employability at older age in light of continuous changes in the labor market. Nevertheless, it is a challenge to sustain the training of employees throughout their professional careers. In particular, this is the case for females, who typically receive less formal workplace training than males. As professional careers of females are characterized by family breaks and periods of part-time work, they are less likely to invest time in workplace training. Since disparities in career paths, in particular between males and females, might lead to differences in training, which then tend to reinforce career inequalities, this paper analyzes the determinants of training not only with a special interest in age but also with a focus on gender.

A detailed analysis of the training gap between males and females requires detailed data and a decomposition capturing the dynamics over professional life. We use personnel records from a single company with a high-skilled workforce from the financial industry. Our outcome variables of interest are the probability to participate in company-provided formal training and the length of training per year. We extend the standard BlinderOaxaca approach and decompose our two outcomes - training probability and training duration - into three terms: an age-specific coefficients effect, an age-specific characteristics effect, and an age composition effect. We additionally include supervisor fixed effects to analyze if supervisors are treating male and female employees differently and we analyze the gender match between supervisor and employee.

Our empirical results show that the divergence in training duration between females and males can mainly be attributed to differences in characteristics (such as wage, working time or hierarchical status). Although birth of children and child care are a plausible explanation of the age pattern of the gender training gap, we cannot find evidence for prebirth training effects and for post birth catching-up effects, which could explain the training investment at higher ages. Furthermore, including supervisor-fixed effects cannot explain the gender differences in training. Supervisors assign more training to all employees if they participate more in training themselves. As companies want women to work more and employees of both genders to work longer, they need to adjust training mechanisms to individual demand. Considering the dynamics in training behavior may help to improve the employability of both male and female workers. 


\section{Das Wichtigste in Kürze}

Betriebliche Weiterbildung gilt als notwendige Maßnahme, um angesichts kontinuierlicher Veränderungen im Arbeitsmarkt die Beschäftigungsfähigkeit im höheren Alter zu erhalten. Gleichwohl ist es schwierig, Erwerbstätige ein ganzes Berufsleben lang weiterzubilden. Dies gilt insbesondere für Frauen, die häufig kürzer an Weiterbildung teilnehmen als Männer. Ihre Erwerbsverläufe sind aufgrund der Geburt und Betreuung von Kindern häufig durch Unterbrechungen und Phasen der Teilzeitbeschäftigung gekennzeichnet, die bei männlichen Erwerbskarrieren kaum eine Rolle spielen, die sich aber in ihrem Weiterbildungsverhalten niederschlagen. Diese Studie untersucht daher die Determinanten des Weiterbildungsverhaltens nicht nur im Hinblick auf das Alter sondern auch mit speziellem Fokus auf die Unterschiede zwischen den Geschlechtern.

Eine Analyse der Differenzen im Weiterbildungsverhalten zwischen Frauen und Männern über den Erwerbsverlauf hinweg erfordert detaillierte Daten und eine Zerlegungsmethode, die in der Lage ist, die Dynamik in den Erwerbsverläufen zu erfassen. Wir nutzen die Personaldaten eines Unternehmens mit hochqualifizierter Belegschaft aus der Finanzdienstleistungsbranche. Das Weiterbildungsverhalten wird anhand von zwei Variablen gemessen: der Wahrscheinlichkeit an betrieblicher Weiterbildung teilzunehmen und der jährlichen Weiterbildungsdauer. Außerdem erweitern wir die Standardzerlegung nach Blinder und Oaxaca und betrachten drei Effekte: einen altersspezifischen Koeffizienten-Effekt, einen altersspezifischen Charakteristika-Effekt und einen Kompositions-Effekt, der die Geschlechterzusammensetzung in den einzelnen Altersstufen widerspiegelt. Eine weitere Zerlegung beinhaltet zudem fixe Vorgesetzten-Effekte, mit deren Hilfe untersucht wird, ob Vorgesetzte bei der Zuweisung von Weiterbildung zwischen Frauen und Männern unterscheiden und wie sich die Geschlechtszuordnung zwischen Vorgesetzten und Mitarbeitern auswirkt.

Die empirischen Ergebnisse zeigen, dass die Differenzen in der jährlichen Weiterbildungsdauer zwischen Frauen und Männern hauptsächlich von Unterschieden in den Charakteristika (wie Gehalt, Arbeitszeit und hierarchische Position) verursacht werden. Obwohl Geburt und Betreuung von Kindern eine plausible Erklärung für den Altersverlauf der geschlechtsspezfischen Unterschiede in Weiterbildung sind, weisen die Daten keine Evidenz auf für negative Effekte vor der Geburt von Kindern und für Aufholeffekte von Frauen, die nach der Elternzeit ins Unternehmen zurückkehren. Auch eine unterschiedliche Behandlung der Geschlechter durch den Vorgesetzten kann ausgeschlossen werden. Vorgesetzte scheinen vor allem dann mehr Weiterbildung zuzulassen, wenn sie auch selbst mehr daran teilnehmen. Die Ergebnisse machen deutlich, dass Unterschiede in der Weiterbildungsbeteiligung zwischen den Geschlechtern und im Alter berücksichtigt werden müssen, wenn Unternehmen die Weiterbildungsbeteiligung von Frauen und Männern, insbesondere - im Hinblick auf die Verlängerung der Lebensarbeitszeit - in höherem Alter fördern wollen. 


\title{
Dips and Floors in Workplace Training: Using Personnel Records to Estimate Gender Differences
}

\author{
Bernd Fitzenberger* and Grit Muehler ${ }^{\dagger}$
}

March 21, 2011

\begin{abstract}
Using personnel records from a single large German firm in the financial industry, this paper provides detailed evidence on the effect of age and the supervisor's gender on gender differences in workplace training, holding constant various workplace characteristics. We implement an age-specific decomposition of the incidence and the duration of training into three terms: an age-specific coefficients effect, an age-specific characteristics effect, and an age composition effect. Our results show that the gender training gap changes with age. Females obtain less training during the early career, and their training occurs at higher age. The timing of the gender training gap seems to be driven by diverging career paths associated with employment interruptions. However, we find no evidence for catching-up effects after parental leave. A decomposition of the training gap including supervisor fixed effects reveals that supervisors do not treat male and female employees differently. Supervisors assign more training to all employees if they themselves participate more in training.
\end{abstract}

Keywords: training participation, age, gender, company data

JEL-classification: M53, M12, J14

Acknowledgements: We would like to thank the company that kindly provided the data. We are grateful to Michael Beckmann, Günther Schulze, and Thomas Zwick for helpful discussions. Part of this work was financed by the German Research Foundation (DFG) through the research project "Personnel Management in Times of Technical and Organizational Change" within the DFG research program "Flexibility in Heterogenous Labor Markets" (FSP 1169). All errors are ours.

${ }^{*}$ University of Freiburg, IFS, IZA and ZEW. Corresponding Address: Department of Economics, Albert-Ludwigs-University Freiburg, 79085 Freiburg, Germany, E-mail: bernd.fitzenberger@vwl.unifreiburg.de.

${ }^{\dagger}$ Centre for European Economic Research (ZEW). Corresponding Address: P.O. Box 103443, D-68034 Mannheim, E-mail: muehler@zew.de. 


\section{Introduction}

The empirical analysis of workplace training has been the subject of numerous studies (Bishop 1996, OECD 1999, 2003, Bassanini et al. 2007). Human capital theory implies that workplace training extends over the entire labor market career (Becker 1964, Mincer \& Polachek 1974). Life-long learning is considered necessary to sustain employability at older age (OECD 2003, Bassanini et al. 2007). The empirical literature finds that training decreases strongly with age. Although the results on the gender effect are ambiguous, a major part of the literature finds that females receive less formal workplace training than males (Bishop 1996, OECD 2003). Furthermore, workplace training varies strongly with a number of workplace characteristics, including education, professions, industries, and firm size. Thus, estimates on gender differences in training may be affected by selection effects. Using personnel records from a single large firm, this paper provides first detailed evidence on the effect of age and the supervisor's gender on gender differences in workplace training, holding constant various workplace characteristics.

The literature (Bishop 1996, OECD 1999, 2003, Bassanini et al. 2007) finds that formal workplace training declines with age and tenure, and that it increases with education and firm size. Married employees receive more training. Training differs strongly by professions and industries. Human capital theory implies such differences in workplace training depending on age and tenure of the employee (Becker 1964). Starting a job, employees receive workplace training to acquire job specific knowledge. More experienced employees may switch to a new job with e.g. broader tasks or greater responsibility, resulting in different training needs. Promotions can provide an occasion to acquire new skills and competencies. Employment interruptions may cause a need for training to catch up with job requirements.

A major part of the literature finds that female employees receive less workplace training than males - although the evidence in the literature is ambiguous. ${ }^{1}$ When restricting workplace training to formal, employer-provided training courses which take place during paid work, the results become more homogeneous. Female employees are equally likely to receive training as males (or slightly less), but their training durations are unambiguously shorter (O'Halloran 2008), in particular when they are young (Bassanini et al. 2007). The gender differences in volumes are more pronounced, when taking a life cycle perspective (Bishop 1996, OECD 2003). Little is known about informal training. However, there seems to be a strong positive correlation between formal and informal training at the firm level (OECD 1999, Bishop 1996).

\footnotetext{
${ }^{1}$ Gender differences in overall training are the subject of a large literature with inconclusive results. Females are found to participate less (Lynch 1992, Royalty 1996, Evertsson 2004, Grund \& Martin 2010), to the same extent (Altonji \& Spletzer 1991, Barron et al. 1993, Veum 1996, Arulampalam et al. 2004, Frazis \& Loewenstein 2006) or more often (Green \& Zanchi 1997, OECD 1999, 2003, Simpson \& Stroh 2002, Bassanini et al. 2007, O'Halloran 2008) in workplace training compared to males.
} 
Male and female age profiles in employment differ strongly, which is likely to result in gender differences in workplace training (Mincer \& Polachek 1974). Anticipating a higher turnover of young female employees in the future, employers may choose to invest less in workplace training of young female employees, even if they are observationally equivalent to young male employees (Becker 1964, Mincer \& Polachek 1974, Barron et al. 1993, Puhani \& Sonderhof 2011). Young female employees may engage in less training because of lower wage returns in light of a persistent wage gap for females and because of lower labor market attachment due to child-rearing in the their late $20 \mathrm{~s}$ or in their $30 \mathrm{~s}$. Employment interruptions or periods of part-time work due to child birth result in shorter amortization periods of training during the early career phase. In accordance with this hypothesis, Puhani \& Sonderhof (2011) find that employer provided training for young female employees fell in response to a policy reform in Germany which expanded maternity leave coverage; this applies to both young female employees with and without children.

A reverse effect may take place when returning full time to the labor market after an employment interruption or a period of part-time work due to child birth. Then, female employees might find it necessary to engage more into workplace training than males of equal age due to greater training needs. Also, these females may use workplace training to signal their high labor force attachment. Fixing a job, Bishop (1996) finds greater training needs the shorter the tenure in the job. Assuming that fixing a job and fixing tenure in the job holds effective career development constant, we stipulate by an analogous argument that training needs are higher after an employment interruption by female employees compared to male employees of the same age but with higher tenure. This reflects either a catching-up of workplace relevant knowledge and competencies or a (re-)start of the career as the investment horizon is now expected to be uninterrupted (Bassanini et al. 2007). Hence, gender differences in career paths can lead to different age profiles in training with growing gender differences in training during the early career phase and a catching up process after child birth at higher age.

Little is known in the literature about how the gender training gap changes as employees age. Most studies do not allow for interaction effects between age and gender, and the scarce existing evidence is based on comparisons between two to three different age groups distinguishing young and old employees (OECD 1999, Bassanini et al. 2007). These studies find a smaller gender gap in training for higher age. To our knowledge, there exists no study which analyzes the age profile of the gender training gap at a yearly frequency, and there exists no study which performs a comprehensive decomposition analysis of the gender specific age profiles in training.

Partly, the ambiguity of empirical results on training in the literature may be caused by the heterogeneity of the data and by measurement problems. Measurement error, heterogeneity in the training needs of industries and firms and in the training programs 
provided by the firms as well as occupational sorting in training participation are critical issues. A great deal of the literature, especially for the US, is concerned with the reliability of the training information used (Bartel 1995, Bishop 1996, OECD 1999). Because of recall bias, training information, which is self-reported by employees, is generally considered less reliable than employer-reported training data. This holds in particular when one wants to distinguish between the incidence and the duration (intensity) of training by employees. Nevertheless, due to lack of employer-reported data, most evidence for Europe is based on training information, which is self-reported by employees (Bassanini et al. 2007, Grund \& Martin 2010). In-depth information on e.g. the content of the training, duration of training, or the background of the participants is not available in household survey data (such as the European Community Household Panel, the National Longitudinal Survey of Youth, or the German Socioeconomic Panel) or in multi-firm data (such as the Continuing Vocational Training Survey). In some cases, detailed employer-reported training data are restricted to recent hirings (Bishop 1996). Observed gender differences in training may be affected by selection effects caused by the sorting of male and female employees into different professions, industries, or firms. Using personnel records for all employees of a single large company, our analysis is a case study in insider econometrics holding firm characteristics and the management strategies constant (Bartel et al. 2004, Ichniowski \& Shaw 2003).

Studies that analyse employer-provided training based on personnel records of single firms are scarce. We are aware of only three studies focussing on the effects of training on wages and other outcomes. Krueger \& Rouse (1998) assess the impact of a specific employerbased education program, Bartel (1995) focuses on the nature of training, i.e. whether it is remedial or used to stimulate career advancement, and Xiangmin \& Batt (2007) examine the productivity effects of informal training. All of the studies find positive impacts of training on either productivity or wages. However, none of them focusses on training participation over age or on gender differences in the participation and duration of training.

Further important issues neglected in the training literature are the training policy of the supervisor, the gender of the supervisor, and the gender match between the supervisor and the employee. The supervisors implement the firm's training strategy, and they may participate in training themselves. Our data provide information of the gender of the supervisor and the level of training received by the supervisor. A first hypothesis to be tested empirically is that the amount of training a supervisor receives has a positive impact on the training of his or her subordinates. The training of the supervisor may also be a proxy for the training needs at the workplace. A second hypothesis relates to the interaction with the same gender (Rothstein 1997, Cardoso \& Winter-Ebmer 2010). Supervisors may have a preference to assign more training to subordinates of the same gender because 
their cooperation involves less frictions. For instance, Cardoso \& Winter-Ebmer (2010) find for Portugal that female employee benefit in female-led firms compared to male-led firms. ${ }^{2}$ Since a majority of supervisors is male, there may on average exist a preference by supervisors for training of male employees. However, the effect may also be reversed if groups of the lower status individuals (e.g. females) tend to identify with members of the higher status group (e.g. males) (Cardoso \& Winter-Ebmer 2010, p. 145). ${ }^{3}$ A third hypothesis focuses on gender differences in supervisor behavior. Following Shakeshaft et al. (1991), female supervisors may assign more training than male supervisors (irrespective of the gender of the subordinates) because female supervisors value competence more strongly and male supervisors value trust more strongly. Melero (2004) emphasizes the importance of gender stereotypes in the management style of supervisors. According to this view, female supervisors favor a more interpersonal and interactive relationship at the workplace, and they engage more in employee-mentoring. In contrast, male supervisors are more task-oriented and follow an authoritarian management style. This line of argument suggests that female supervisors assign more formal training than male supervisors, irrespective of the gender of the subordinates. Borghans et al. (2004) emphasize that female employees have better interactive skills ('people people'). Therefore, female supervisors may be better able to assess training needs, and they have a better supervision style than male supervisors. Because female supervisors and female employees may be strongly selected into specific professions, industries, or firms, it is important to have access to firm level data (Rothstein 1997), which allows to control pertinent selection effects. Note that the financial industry implements a larger amount of formal training in comparison to other industries (OECD 1999). Hence, it is important a forteriori to control the firm level environment when analyzing the gender match of supervisors and employees.

Our paper makes four contributions. First, our paper is the first to decompose the continuous age profile of the gender differences in workplace training. As one methodological contribution, the paper demonstrates how to extend a standard Blinder-Oaxacadecomposition approach to estimate the age specific characteristics effect, the age specific coefficient effect, and the age composition effect. Second, our paper uses very reliable firm level data for four years on all employees in a large firm in the financial industry. The training data are based on the training reporting system of the company which is used for controlling purposes. The data allow to analyse both the incidence and the duration of training by year. Third, our paper is the first to analyse empirically the impact of

\footnotetext{
${ }^{2}$ The study finds that female employees show higher wages in female-led firms. Cardoso \& WinterEbmer (2010, p. 144) suspect that preferences may result in mentoring one group of employees by help in career progression and access to on-the-job training and neworks. For this effect, Cardoso \& WinterEbmer (2010, p. 145) refer to the similarity-attraction paradigm in social psychology.

${ }^{3}$ For this possible effect, Cardoso \& Winter-Ebmer (2010) refer to the concept of the self-enhancement drive in social psychology (Graves \& Powell 1995).
} 
both the training behavior and the gender of the supervisor on the amount of training and the gender training gap among the subordinates. Fourth, as a second methodological contribution, the paper suggests to use a weighted block bootstrap approach (Barbe \& Bertail 1995) for the decomposition results based on probit regressions for the incidence of training. This approach eliminates estimation problems in the resamples (perfect predictions, perfect collinearity of covariates), and we adapt the approach to estimate clustered standard errors of the decomposition estimates based on panel data.

Using data from one large internationally operating company from the financial industry, we provide a detailed analysis of the gender training gap by age. Being close to zero at the age of 25, the gap grows during the first 10 years and peaks at age 35 with females on average having a 0.75 days shorter training duration per year. Based on a age-specific decomposition analysis, we find that this divergence in training behavior can be mainly attributed to differences in characteristics (such as wage, working time or hierarchical status), which evolve as employees age. Although fertility seems to be responsible for diverging careers between males and females, we cannot find evidence for catching-up effects, which could explain the training investment at higher ages. Further, including supervisor-fixed effects cannot explain gender differences in training. Supervisors do not treat males and females differently. They assign more training to all employees if they also participate more in training themselves.

The next section presents more detailed information on the company and personnel records we use, and it describes the outcome variables and explanatory factors of interest. The decomposition approach is outlined in Section 3. Section 4 presents results and discussion, and Section 5 concludes.

\section{Data}

We use data from a high-paying company with a high-skilled workforce in the financial industry in Germany. From the human resources department we received administrative personnel records on all of the company's employees based in Germany for the years 2004 to $2007 .^{4}$ In addition, we obtained for each of these years the training records on those employees who participated in one of the training courses provided by the company. The continuous training programs offered by the employer involve around 3,000 courses. Participation is organized using a special software. The software was introduced in 2003 and it is used to carry out all the steps necessary for participation in the company's training programs: information research, signing up, and approval of the supervisor. The company leaves training decisions to the responsibility of its employees and thereby aims

\footnotetext{
${ }^{4}$ The reporting date is 31 st of December in each year.
} 
at encouraging an active interest in one's own lifelong learning. As we do not have any information on informal training such as learning-by-doing, observing co-workers or by simply asking colleagues (which are in addition very difficult to measure), we restrict the analysis to formal training courses, provided and paid by the employer. ${ }^{5}$ For the four years we have 131,130 observations, among them 69,907 (53.3\%) for females und 61,223 $(46.7 \%)$ for males.

We make some adjustments regarding courses and individuals included. Regarding courses included, the main adjustment concerns involuntary training. As the company operates in the financial sector, it is obliged by law to guarantee that the employees can always comply with legal requirements. Thus, a part of the courses is mandatory for all employees. Therefore, we drop participation in these mandatory courses. Furthermore, we include only completed courses. Regarding the individuals included, we drop all individuals who are younger than 25 years or older than 50 years to avoid unusual training behavior due to the start or end of the professional career. For the same reason, we also drop trainees, interns, and expatriates. Our final sample consists of 101,889 observations, $54,793(53.8 \%)$ females and 47,096 (46.2\%) males. The adjustment with respect to the age range considered does not change the gender ratio compared to the original data set. Table A.1 in the appendix displays the gender distribution by age profile in our sample. The share of females among employees falls from $60 \%$ at age 25 to $48 \%$ at age 50 .

Training characteristics covered in the data are training incidence, training intensity (number, length of course) and training category such as business, information technology, professional qualifications. Our main outcome variables of interest are training participation and number of training days per year. Training participation is a dummy variable which takes the value one when the employee participates in at least one training course per year and zero otherwise. Training duration per year is calculated based on the days and hours spent in formal employer provided training. ${ }^{6}$ If the training period is longer than five consecutive days, the calculation is adjusted to weekdays. When a training course stretches across more than one calendar year, the respective duration within one calendar year is assigned to this year.

The average training gap between males and females (gender training gap) is 6 percentage points for training incidence and 0.38 training days per year for training duration (see

\footnotetext{
${ }^{5}$ Most job training is informal, however (Bishop 1996). But as Veum (1995) points out, informal training such as learning-by-doing, observing co-workers or by simply asking colleagues is very difficult to measure.

${ }^{6}$ Training duration is set to zero for individuals who do not participate in company provided training in a specific year. The summary statistics and the regressions for training duration include these individuals. As a robustness check regarding the sensitivity to outliers, estimation of training duration was also implemented using a tobit regression, where long training durations are artificially censored at 20 days per year because of observations with very long training durations. As the results of the linear regression and the tobit regression are similar, we report only the linear regressions for the estimation of training duration.
} 
Table 1: Means of variables by gender

\begin{tabular}{lll}
\hline variables & males & females \\
\hline outcome variables & & \\
$\quad$ participation rate & 0.58 & 0.52 \\
training days per year & 2.19 & 1.81 \\
explanatory variables & & \\
age & 38.06 & 37.45 \\
school degree (in \%) & 0.03 & 0.07 \\
vocational degree (in \%) & 0.34 & 0.51 \\
university degree (in \%) & 0.51 & 0.31 \\
wage (in 1,000 Euro) & 58.37 & 38.76 \\
tenure (in years) & 14.86 & 15.44 \\
working part-time (in \%) & 0.05 & 0.45 \\
corporate title (in \%) & 0.73 & 0.41 \\
supervisor (in \%) & 0.20 & 0.06 \\
\hline$N \quad$ & 47,096 & 54,793 \\
\hline
\end{tabular}

Table 1). A closer look shows that the gap in training participation and duration varies considerably by age. Figure 1 shows the average training duration by age and gender. Starting from nearly equal participation rates and durations for employees in their mid twenties, the gender specific profiles diverge during the first 10 to 15 years of professional life. As Figure 1 shows, the gap in training duration between males and females is largest at age 35 when females have 0.75 days per year less training than males. Above age 35, the gap starts to close again, and at age 50, it amounts to 0.2 days per year. Therefore, female training investments are lower on average, and the gap is strongest during the mid 30 s.

As most of the divergence in training occurs between age 25 and 40, childbirth followed by a period of parental leave is a likely explanation for diverging training paths. However, training behavior could as well just reflect divergence in other career related factors such as wage, working time or hierarchical status. Table 1 shows the differences between males and females in these characteristics. The average earnings are 58,000 Euro for males and 39,000 Euro for females. ${ }^{7} 95 \%$ of the male and $55 \%$ of the female employees work full-time. The corporate title is an important indicator for the hierarchical level of the employees' position. $73 \%$ of the male employees and $41 \%$ of the female employees hold a corporate title. Possessing a title is not necessarily connected with managerial (supervisory) responsibility. $20 \%$ of the males but only $6 \%$ of the females in our sample are supervisors.

\footnotetext{
${ }^{7}$ The variable describes the basis wage, which does not include bonuses or other extra-payments. In the regressions in the following section, wage is expressed in dimension 1,000 Euro.
} 
Figure 1: Age profile of training duration

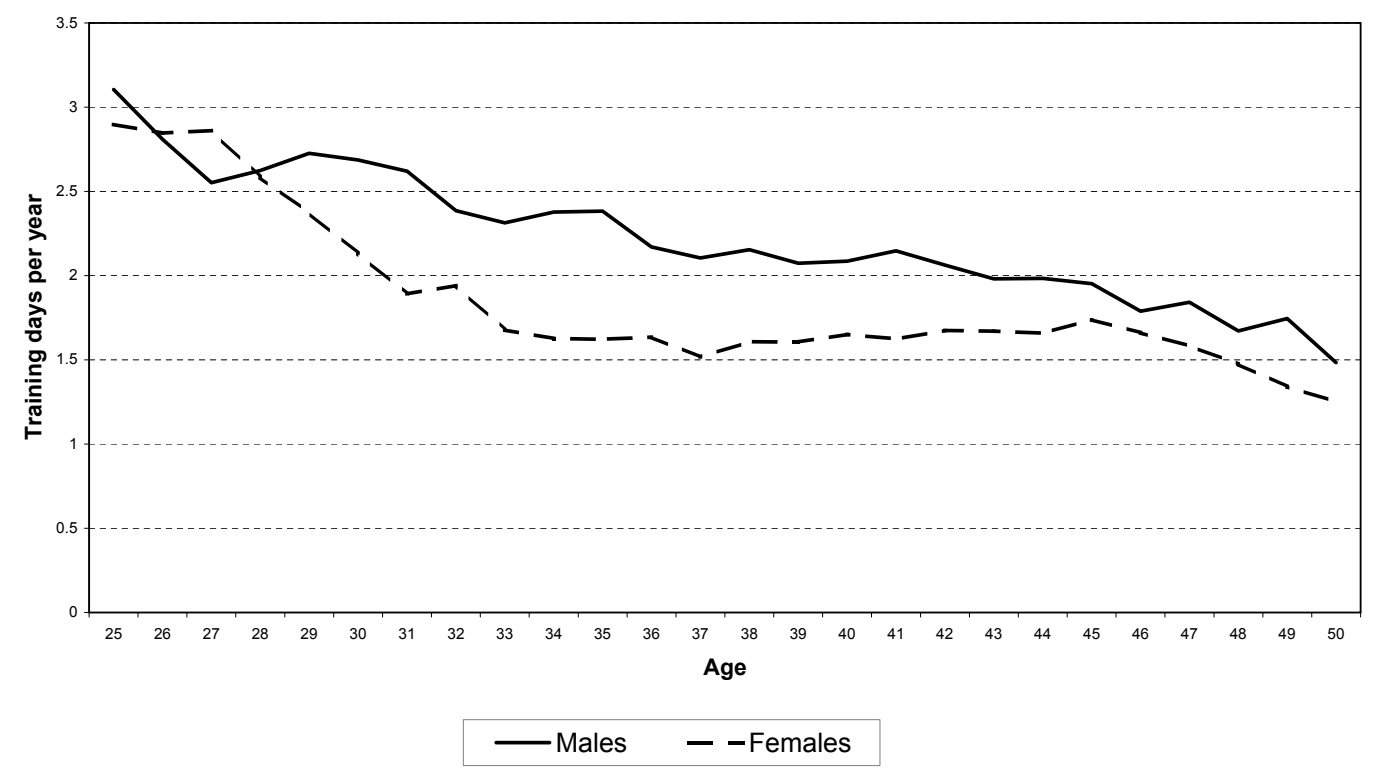

The difference in individual characteristics and job characteristics (such as wage, working time or hierarchical status) between females and males is widening during the first ten years of their professional career. Figure A.1 in the Appendix depicts the age profiles of wages, working time, and the share of females both among all employees and among supervisors. As the graphical evidence shows, these characteristics evolve differently for the two groups. For example, the working time decreases for females until age 35. At this age, the average woman works $62 \%$ of a full-time contract, whereas the average male of the same age works $98 \%$. The development of this and the other individual and job characteristics are likely to be associated with differences in training participation and duration. We decompose the outcome variables by age to analyse in more detail to which extent the gap is driven by differences in characteristics and by differences in coefficients associated with these characteristics.

\section{Decomposition Approach}

The aim of our econometric analysis is to investigate the gender gap in training probability (incidence) and in training duration by decomposing age-specific differences. We consider individuals from age 25 to age 50 grouped in 26 age cells. This decomposition approach extends the standard Blinder (1973) and Oaxaca (1973) decomposition by decomposing the characteristics and the coefficients effects along the age dimension and by accounting for a separate age "composition effect". Our two outcomes - training probability and training duration - are decomposed into three terms: an age-specific coefficients effect, an 
age-specific characteristics effect, and an age composition effect. This last effect captures the changing gender composition over the age groups. The following two sections describe the counterfactual outcomes and the decomposed effects for training duration and for training probability.

\subsection{Decomposition of Training Duration}

The decomposition of training duration is based on separate linear regressions for males and females. The decomposition for the number of training days per year can be written in a formal way as follows. The two groups males $(M)$ and females $(F)$ and the difference in the mean outcomes of females $\left(\bar{Y}_{F}\right)$ and males $\left(\bar{Y}_{M}\right)$ are of interest to us. The difference in mean outcomes is given by

$$
\bar{Y}_{F}-\bar{Y}_{M}=\bar{X}_{F} \hat{\beta}_{F}-\bar{X}_{M} \hat{\beta}_{M}
$$

Accounting for each year of age between 25 and 50 separately, our age profile is based on 26 different age cells $a=25, \ldots, 50$. Thus, the difference in outcomes can be written as

$$
\bar{Y}_{F}-\bar{Y}_{M}=\sum_{a=25}^{50} h_{a}^{F} \bar{Y}_{F, a}-\sum_{a=25}^{50} h_{a}^{M} \bar{Y}_{M, a}=\sum_{a=25}^{50} h_{a}^{F} \bar{X}_{F, a} \hat{\beta}_{F}-\sum_{a=25}^{50} h_{a}^{M} \bar{X}_{M, a} \hat{\beta}_{M},
$$

where $h_{a}$ denotes the weight of an age cell calculated as number of males or females in the respective age group divided by the total number of males or females, respectively. The equation is expanded by two terms: First, by adding and subtracting $\sum_{a=25}^{50} h_{a}^{M} \bar{X}_{M, a} \hat{\beta}_{F}$, which is the counterfactual based on male characteristics (by age), female coefficients, and the male age composition (CharM-CoefF-AgeM), i.e. the duration if males had female coefficients weighted by the share of males in the respective age group $a$. Second, by adding and subtracting $\sum_{a=25}^{50} h_{a}^{M} \bar{X}_{F, a} \hat{\beta}_{F}$, which is the counterfactual based on female characteristics (by age), female coefficients, and the male age composition (CharF-CoefFAgeM), i.e. the duration of females weighted by the share of males in the respective age group $a$. Rearranging the terms results in the three effects of interest:

$$
\begin{gathered}
\sum_{a=25}^{50} h_{a}^{F} \bar{Y}_{F, a}-\sum_{a=25}^{50} h_{a}^{M} \bar{Y}_{M, a}= \\
\sum_{a=25}^{50} h_{a}^{M}\left[\bar{X}_{M, a}\left(\hat{\beta}_{F}-\hat{\beta}_{M}\right)+\left(\bar{X}_{F, a}-\bar{X}_{M, a}\right) \hat{\beta}_{F}+\left(\frac{h_{a}^{F}-h_{a}^{M}}{h_{a}^{M}} \bar{X}_{F, a} \hat{\beta}_{F}\right)\right] .
\end{gathered}
$$

Equation (3) shows that the difference between the group means of training days per year involves three terms, which can be expressed as a function of age. The first term 
$\bar{X}_{M, a}\left(\hat{\beta}_{F}-\hat{\beta}_{M}\right)$ reflects the age specific coefficients effect, i.e. the average change in male training days if males had female coefficients. The second term $\left(\bar{X}_{F, a}-\bar{X}_{M, a}\right) \hat{\beta}_{F}$ is the age specific characteristics effect, i.e. the average change in male training days if assigned female characteristics. The third term $\frac{h_{a}^{F}-h_{a}^{M}}{h_{a}^{M}} \bar{X}_{F, a} \hat{\beta}_{F}$ is the effect which captures the gender composition in each age cell weighted with the relative difference between males and females in the respective age group.

Our decomposition uses the counterfactual based on male characteristics and female coefficients, thus, evaluating differences in coefficients at male characteristics and differences in characteristics at female coefficients. We assess the differences in the age composition at average female training variables. Our calculation of age-specific effects relies on two counterfactual outcomes instead of one as the standard Blinder-Oaxaca decomposition. We denote the counterfactual outcome that is needed to calculate the coefficients and characteristics effect by age as CharM-CoefF-AgeM. This is the outcome that would prevail if males kept their characteristics but participated in training in the same way as females - or, to put it differently, if females were assigned male characteristics but assignment conditional on characteristics was still according to female coefficients. ${ }^{8}$ The coefficients effect explains the differences in training participation due to gender specific differences in coefficients. Our age specific coefficient effect aggregates to the coefficients effect known from the standard Blinder-Oaxaca decomposition. The age specific characteristics effect accounts for differences in the characteristics within one age group. ${ }^{9}$ As shown in Section 2 and Figure A.1, females and males differ, for instance, in terms of wage, working time, supervisory status, and the age composition.

Three outcomes - the actual male and female outcome and the counterfactual CharMCoefF-AgeM - are calculated within an age cell. To fully assess the age-specific decomposition, these age cells have to be weighted to reflect the importance of an age group with regard to the total number individuals for each gender. The fourth outcome, i.e. the counterfactual CharF-CoefF-AgeM accounts for the changing gender composition across age groups (see Table A.1). This "counterfactual female outcome" is the male-weighted outcome for females in each age cell. ${ }^{10}$ The composition effect is calculated as the difference of the counterfactual female outcome and the actual outcome observed for females. Thus, the composition effect picks up the change in characteristics, which occurs due to the changing gender composition along the age profile.

\footnotetext{
${ }^{8}$ Due to the age-specific decomposition, the outcome in each age cell is weighted in addition by the share of males in the respective age group among all male employees.

${ }^{9}$ Again, the outcome in each age cell is weighted by the number of males respective age group in relation to the total number of males.

${ }^{10}$ The outcomes are weighted with the number of males respective age group in relation to the total number of males.
} 
Standard errors and confidence intervals for the age-specific effects are obtained by bootstrapping individuals with 1,000 replications to obtain clustered standard errors at the individual level, which account for the correlation of the observations of the same individual over time (cluster bootstrap, see Cameron et al. 2008).

\subsection{Decomposition of Training Probability}

The decomposition for training participation applies the Fairlie (2005) decomposition for a probit model of the training probability in the two groups. The decomposition parallels the decomposition in the linear case with the slight difference that probabilities instead of linear predictions are used for calculating the counterfactual outcomes.

Analogous to the previous subsection, we account for the age-specific characteristics effect, the age-specific coefficients effect and the age composition effect. This leads to the following decomposition:

$$
\begin{gathered}
\overline{Y_{F}}-\overline{Y_{M}}=\overline{\Phi_{F}}-\overline{\Phi_{M}}=\overline{\Phi\left(X_{F} \hat{\beta}_{F}\right)}-\overline{\Phi\left(X_{M} \hat{\beta}_{M}\right)} \\
\left.=\sum_{a=25}^{50} h_{a}^{M}\left[\overline{\left[\Phi\left(X_{M, a} \hat{\beta}_{F}\right)\right.}-\overline{\Phi\left(X_{M, a} \hat{\beta}_{M}\right)}\right]+\overline{\Phi\left(X_{F, a} \hat{\beta}_{F}\right)}-\overline{\Phi\left(X_{M, a} \hat{\beta}_{F}\right)}\right] \\
\left.+\left[\frac{h_{a}^{F}-h_{a}^{M}}{h_{a}^{M}} \overline{\Phi\left(X_{F, a} \hat{\beta}_{F}\right)}\right]\right]
\end{gathered}
$$

where $\overline{\Phi\left(X_{M, a} \hat{\beta} .\right)}$ and $\overline{\Phi\left(X_{F, a} \hat{\beta} .\right)}$ are the sample means for males and females, respectively, at age $a$ for coefficient vector $\hat{\beta}$. .

Similar to the decomposition for training duration, the first term reflects the age specific coefficients effect, i.e. the average change in male training probability if males had female coefficients. The second term is the age specific characteristics effect, i.e. the average change in the training probability if employees were assigned either female or male characteristics, evaluated at female coefficients by age. The third term is the effect which captures the gender composition in each age cell weighted by the relative difference between males and females in the respective age group.

Because of the underlying probit model, we suggest to estimate standard errors using a weighted bootstrap approach instead of a standard bootstrap (for a formal description of the basic weighted bootstrap, see Barbe \& Bertail 1995). The standard errors and confidence intervals are calculated based on 1,000 bootstrap replications. The weighted bootstrap avoids numerical problems as the procedure prevents resamples with perfect collinearity of regressors or perfect predictions caused by the use of dummy variables. 
Both problems would occur for a standard pairwise bootstrap when accidentally only observations are drawn into the resample for which the dependent variable is zero (or one) for all observations in certain cells (such that the probit would try to predict an exact zero [or an exact one] for such observations) or one of the explanatory dummy variables are all zero (or one) for all observations.

Technically, our weighted bootstrap procedure assigns a randomly drawn weight to each individual to include all (weighted) observations into the estimation instead of drawing only a subset of observations, which are drawn at least once, as down in the standard pairwise bootstrap. Specifically, for the weighted bootstrap, we draw the weights from a uniform distribution on the interval $[0,2]$. Therefore, the weights have a mean of one and a variance of $1 / 3$. As drawing from this interval underestimates the variance by a factor of three, the obtained bootstrap variance-covariance matrix has to be multiplied by three. We suggest to assign the same weight for one individual over time, which implies that standard errors are clustered at the individual level.

\section{Results}

The results of the decomposition are presented in three steps. First, we show the agespecific decomposition outcomes for training duration and training incidence. Second, we exclude individuals on parental leave to assess how the training gap and the age profile of the decomposed effect changes once child birth and leave periods are considered. Third, we repeat the first two decompositions including supervisor fixed effects to capture effects of different assignment of training by the supervisor according to gender.

\subsection{Decomposition}

The decomposition starts by estimating the underlying regressions for training participation and training duration separately for males and females. We include yearly age dummies, controls for individual and job characteristics (as described in Table 1), as well as dummies for years and missing values. In addition, we include interactions between the covariates and age to obtain a sufficiently flexible fit to the data. The results of these regressions are displayed in Tables A.2 and A.3 in the Appendix. The reference individual is 25 years old, holds a vocational degree, works fulltime, and does neither have a corporate title nor a supervisory role.

The results show that education and age, besides gender, are the most important factors for training participation and duration, besides gender. Both the probability to participate in company training and the duration of training decrease severely with age. Regarding 
Figure 2: Age profile of actual and hypothetical training durations per year

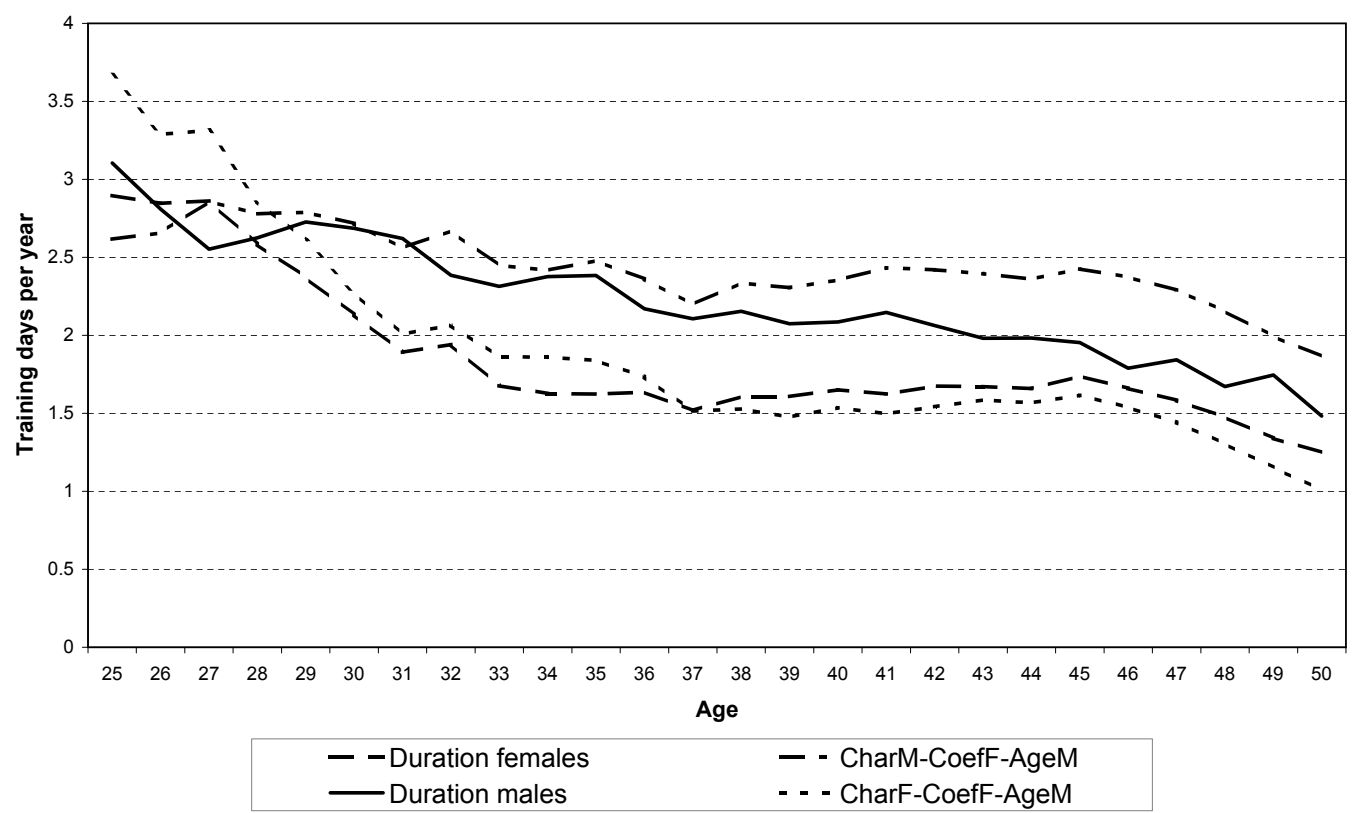

CharM-CoefF-AgeM is the counterfactual duration, if males had female coefficients. CharF-CoefF-AgeM is the counterfactual duration of females reweighted to the share of males in the respective age group $a$, see Footnotes 11 and 12 for a detailed explanation.

economic significance, the effects increase the older the employees are. Compared to the under 25-year-olds, male employees aged 50 participate three days less in training per year, female employees 2.7 days less. Furthermore, our results suggest that effects are not the same for males and females. As this cannot easily be seen when comparing separate regressions, we perform a joint regression using the same specification and add a gender dummy and gender-age dummies in five year intervals. Results are displayed in Table A.4. The interaction terms on gender and age reveal age specific differences between males and females. Females who are older than 41 are more likely to participate in company provided training than males in their age group. For training duration, this effect is present at all ages. However, the gender dummy is larger and negative, resulting in the training gap as shown in Table 1. We conclude that females and males exhibit different age profiles in their training participation. A simple comparison of mean outcomes as shown in Table 1 reveals the gender differences, but it cannot show the development by age. Henceforth, our decomposition takes that into account by estimating age specific coefficients and characteristics effects.

We apply the decomposition in Equation (3) for training duration and in Equation (4) for training incidence. The actual and counterfactual outcomes used to calculate the three effects are displayed in Figure $2 .{ }^{11}$ The solid and the dashed line are the actual durations

\footnotetext{
${ }^{11}$ The calculation for this figure (and all following figures) is made without weighting the outcomes with $h_{a}^{M}$. This allows to directly read the number of training days (the training probability) from the
} 
for males and females as already displayed in Figure 1. The triple-dashed line at the top is the counterfactual male outcome, i.e. the duration if males had female coefficients, and the dotted line at the bottom is the counterfactual female outcome, i.e. the female duration reweighted by the relative age-composition difference between males and females. ${ }^{12}$ The figure shows that males would do more days of training, especially from age 37 onwards if assigned female coefficients (triple-dashed line). This indicates a coefficient effect which rises with age. Similarly, the counterfactual reweighted female duration (CharF-CoefFAgeM, dotted line) lies above the actual female outcome for females younger than age 37 and below for females from age 37 onwards. The rise in the share of male workers by age results in a positive (negative) effect below (above) age 37.

As displayed in Equation (3), the three effects of interest can be obtained by drawing the differences between the hypothetical and actual outcomes. Figure 3 displays the results of plotting the values of these three effects and their $95 \%$ confidence intervals over age. The respective regressions and standard errors are included in Table A.5 in the Appendix.

As Figure 3 shows, the three effects are not constant over age. The coefficients effect (solid line) reveals that if males were assigned female coefficients, their training duration would rise, driven by an increase in the female coefficients effect starting from age 37 onwards. However, this effect is by far outweighed by the characteristics effect (dotted line). When males are assigned female characteristics, training duration sharply declines until age 35 and then stabilizes until age 50. The characteristics of males and females are diverging in the first ten years of professional life (cumulating in a maximal characteristics effect of -0.85 training days at age 35) but apparently not beyond that period. Nevertheless, this difference strongly affects the duration of training. The shape of the coefficients effect suggests that either the females themselves or the company try to compensate the adverse characteristics effect. The dotted line ('comp') denotes the age composition effect showing a positive effect at young age (due to the higher share of females) and a negative effect at older age (due to the lower share of females). The overall gap is widened between ages 25 and 35 due to the sharp increase in the characteristics effect and narrowed from age 37 on due to the increase in the coefficients effect. This suggests that females respond differently in their training investments later in their careers compared to males.

The overall average training gap of -0.38 days (female minus male) can be decomposed by using the weighted sums of the three terms as shows in Equation (3). The characteristics effect largely outweighs the two other terms and accounts for -0.64 days. The average

vertical axis. Only the counterfactual outcome for CharF-CoefF-AgeM is reweighted to accommodate the fact that Equation (3) weights by the age composition of males $h_{a}^{M}$ where the age composition of females $h_{a}^{F}$ is needed to calculate the outcome.

12 The counterfactual outcome for CharF-CoefF-AgeM is displayed in a reweighted way to accommodate the fact that Equation (3) weights by the age composition of males $h_{a}^{M}$. The profile for CharF-CoefFAgeM in Figure 2 is calculated as $\frac{h_{a}^{F}}{h_{a}^{M}} \bar{X}_{F, a} \hat{\beta}_{F}$ (see also Footnote 11). 
Figure 3: Age profile of gender decomposition in training days per year

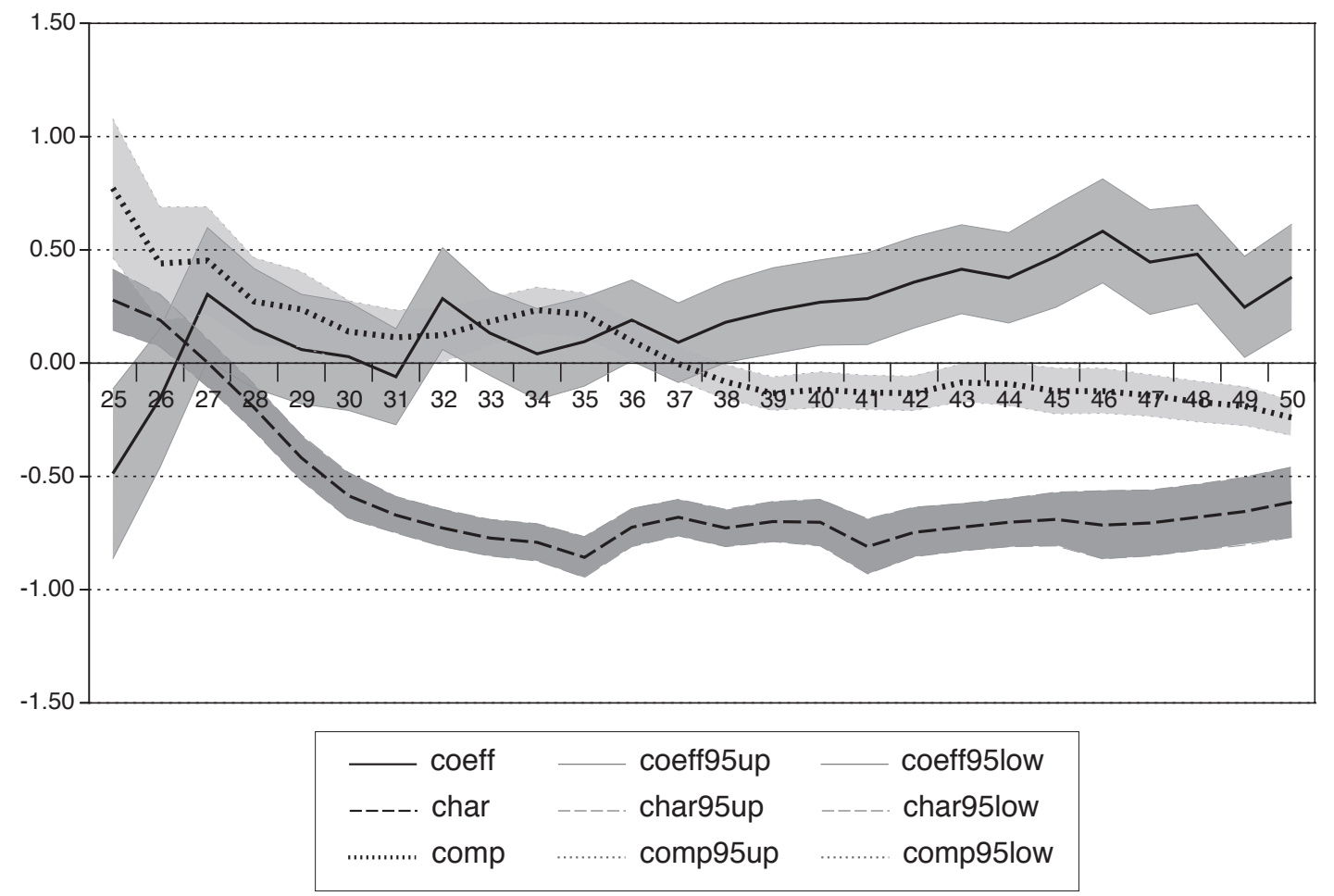

The coefficients effect (coeff) is indicated by the solid line, the characteristics effect (char) by the dashed line, and the composition effect (comp) by the dotted line. The confidence intervals are depicted by the grey shades, with the respective upper (95up) and lower (95low) confidence bounds in the same shape as the graphs for the effects.

coefficients effect is 0.23 days, and the average composition effect accounts for 0.03 days. As Figure 3 shows, the age-specific effects are not constant over time. Thus, a standard Blinder-Oaxaca decomposition would miss the dynamics.

The results for the participation equation are similar although largely insignificant. Figure 4 shows the decomposed gap in the probability to participate in company provided training. The respective regressions and standard errors are included in Table A.6 in the Appendix. The overall difference of 6 percentage points is on average nearly fully explained by the characteristics effect. The average coefficients effect is close to zero as well as the average composition effect. Again, the age-specific effects are not constant. In particular, the coefficients effect rises substantially and significantly from age 39 onwards. This again suggests that particularly training investments of females change late in the career. Summing up the results from the first part of the analysis, female training investments are lower, especially in the thirties and forties, because of the deteriorating females characteristics relative to males between age 25 and 35 and because, relative to males, training of females is postponed to some extent to a later age. 
Figure 4: Age profile of gender decomposition in training incidence

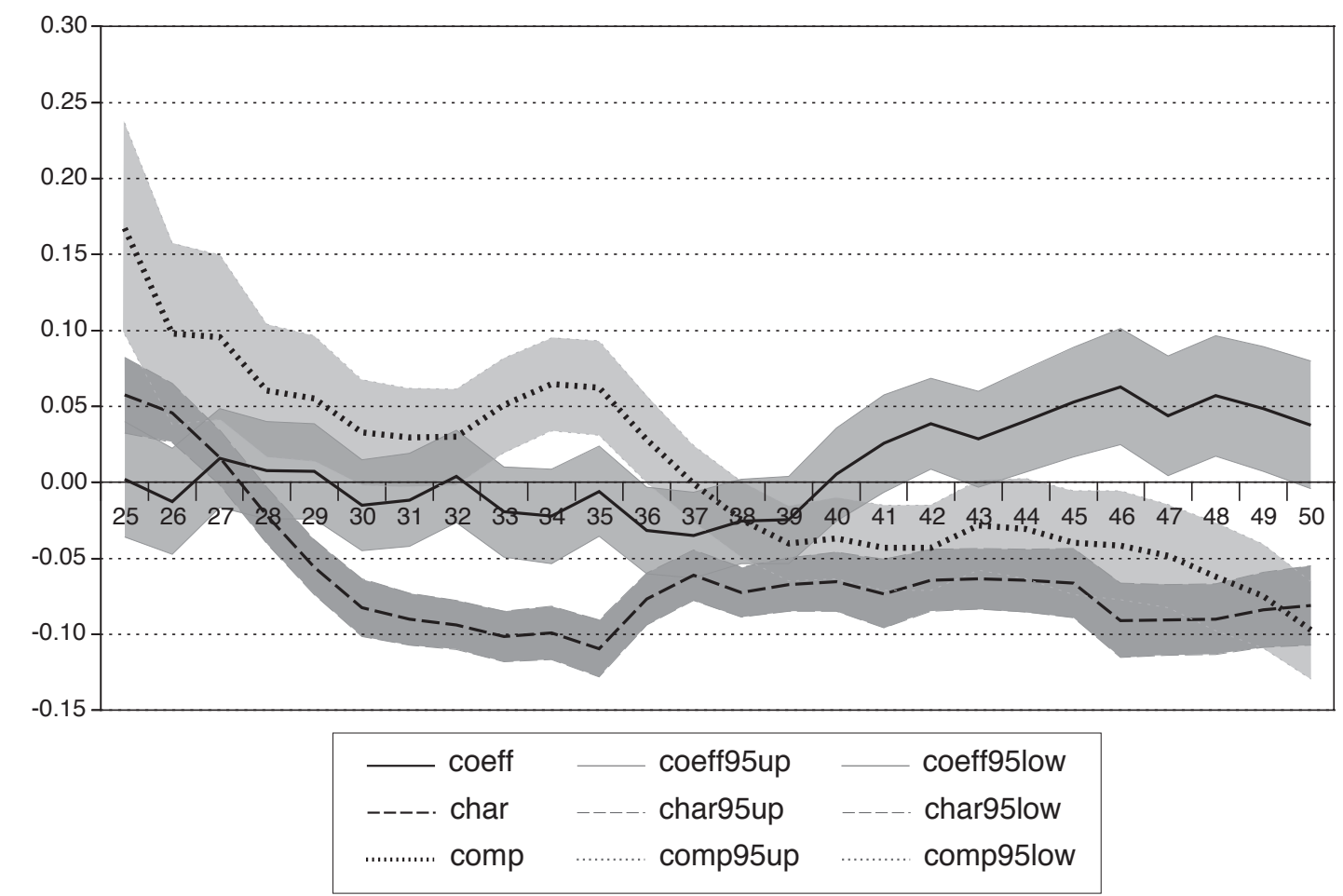

The coefficients effect (coeff) is indicated by the solid line, the characteristics effect (char) by the dashed line and the composition effect (comp) by the dotted line. The confidence intervals are depicted by the grey shades, with the respective upper (95up) and lower (95low) confidence bounds in the same shape as the graphs for the effects.

\subsection{Parental Leave}

One reason why females invest later in training compared to males might be professional catching-up after parental leave. Although both groups probably start with the same investments in training, family formation may cause female career paths and training participation to fall behind those of males. When returning to their jobs after a family related break, females might have the need to invest heavily to catch up professional knowledge. This could result in the higher participation and longer duration in companyprovided training during that stage of professional life as shown in Figure 1 and as reflected in the positive coefficients effect in Figure 3.

As the gender characteristics gap develops between age 25 and 35, it is plausible that diverging female career paths lead to the substantial training investments from the midthirties onwards. To analyse whether such a "catching-up" process plays a role in explaining the training behavior over the professional life career, we exclude individuals on parental leave. ${ }^{13}$ Figure 5 shows the results for the decomposed duration of training when individual-year-observations on parental leave are excluded.

\footnotetext{
${ }^{13}$ Our data records individuals on parental leave whose job in the company is protected for a maximum of 3 years after childbirth.
} 
Figure 5: Age profile of gender decomposition in training duration (excluding individuals on parental leave)

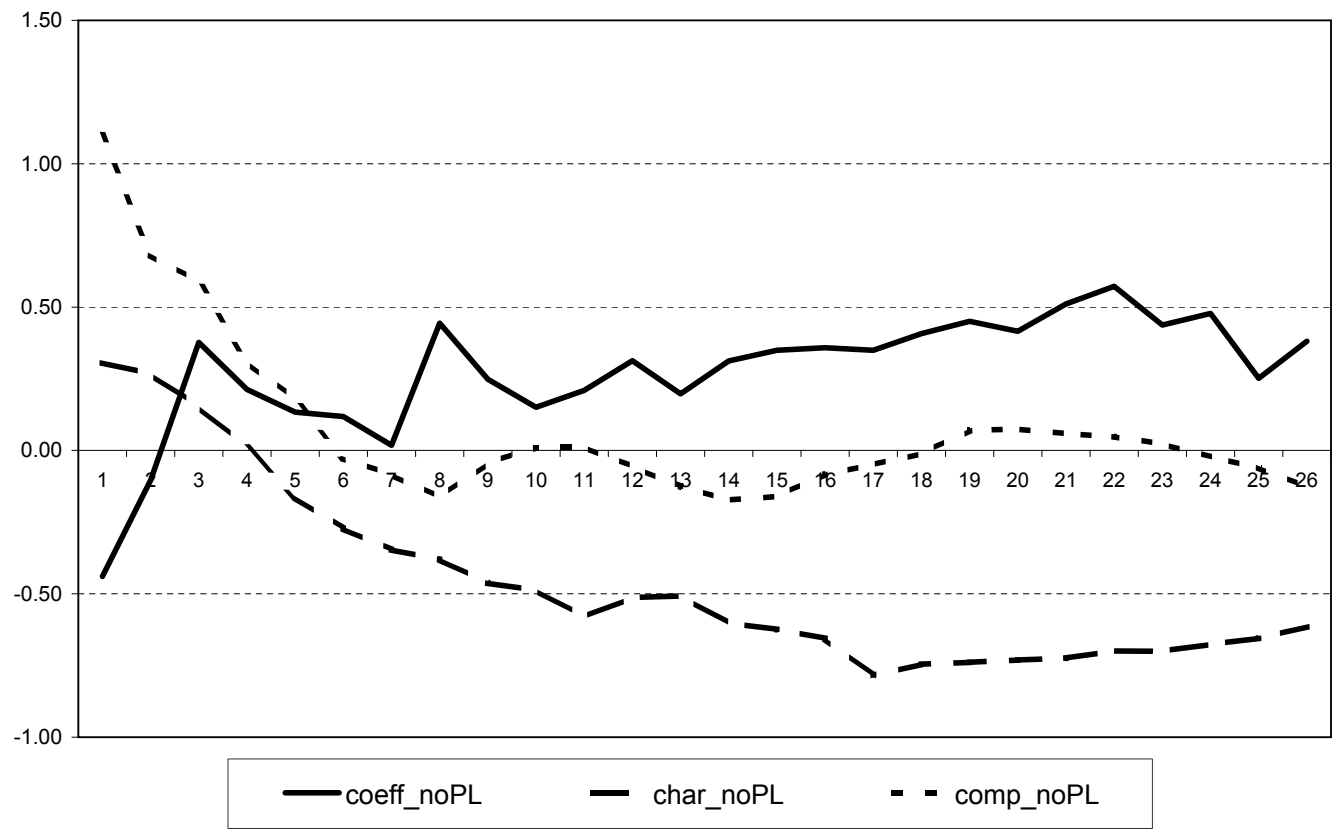

The coefficients effect for the sample excluding individuals on parental leave (PL) is indicated by the solid line (coeff_noPL), the characteristics effect (char_noPL) by the dashed line and the composition effect (comp_noPL) by the dotted line.

During the years 2004 to 2007, we observe 5,637 individuals (5.5\%) in parental leave. Nearly all of them are females (98.6\%). Only 98 individuals (1.8\% of individuals in parental leave) have observations on working time that are non-zero. 277 (5\%) take part in training activities during that time. As Figure 5 shows, excluding these observations flattens the characteristics effect in the first part of the age profile. Thus, the impact of characteristics is lower (the average is -0.51 days per year) compared to the characteristics effect in the non-restricted sample (where the average was -0.64 days per year). As we are mainly excluding observations with zero working time, the impact of the characteristics effect is lower. This occurs because working time is one of the characteristics diverging the most between males and females in the early years of a professional career (see Figure A.2 in the Appendix). The coefficients (0.25 days on average) and composition effect (0.03 days on average) are slightly more pronounced during that first part of the age profile. However, the development of the three effects is nearly unaffected over the second part of the profiles. In particular from age 41 onwards, the characteristics effect lies at about the same level as before, and the coefficients effect rises as before.

We estimate linear regressions as above to compare the duration of training of the individuals before and after parental leave to females employees not in parental leave (detailed 
results are available upon request). ${ }^{14}$ The regressions include dummy variables for periods shortly before and shortly after parental leave. The regression results show that females who are going to leave in the next one, two, or three years receive about the same amount of training (1.85 days per year) as other female employees. Looking at observations in the first or second period after return from parental leave reveals that their training is substantially shorter (0.4 days per year). Including dummy variables measuring the years before and after parental leave in the linear regression on training duration for females shows no significant rise in training before the leave but a significant drop after returning. Thus, females do not seem to accumulate human capital "in advance" anticipating a drop in human capital investment during parental leave but they are not investing strongly directly after returning from parental leave either. We conclude that although observations on parental leave seems to be responsible for diverging characteristics between males and females during the late twenties and early thirties, there is no evidence for catching-up effects that would explain the substantial investment in training of females during the second half of professional life.

\subsection{Supervisor Fixed Effects}

One might suspect that the lower training investment of females is due to different assignment by supervisors (Rothstein 1997, Shakeshaft et al. 1991, Melero 2004). Since careers of females are more likely to involve parental leave and (periods of) part-time work, supervisors may assign less workplace training to female employees. Supervisors may prefer employees of the same gender and the own training of the supervisor may reflect his/her training policy. In the following, we explore the effect of the supervisor and his/her characteristics (including gender) on the duration of training received by males and females. To do this, we first estimate supervisor fixed effects by gender of employee. We analyse how the size of the fixed effects depends upon supervisor characteristics and the gender match between supervisor and employee. Finally, we again decompose the gender training gap including supervisor fixed effects.

To estimate supervisor fixed effects for training of the subordinates, we estimate the OLS training regressions reported in Table A.3 by gender on the sample of observations for which we have information on the supervisor of the employee. We interpret the supervisor fixed effects as the "baseline duration" of training which is assigned to males and females irrespectively of their individual and professional characteristics. We center the explanatory variables around their respective means in the overall sample to obtain comparability between male and female employees. The 5,372 supervisors we observe in

\footnotetext{
${ }^{14}$ Unfortunately, we have only four years of data, so that we cannot follow females for a longer period after they return. Further, a large part of females is in parental leave during the whole period we observe so that we only have very few observations (147) which return at all during the four years.
} 
the sample can have solely male employees, solely female employees, or employees of both genders. Thus, we end up with a (stacked) sample of 22,925 supervisor-year observations, for which we have fixed effects and additional information on the supervisor. We truncate these observations from below and from above (at the 2nd and 98th percentile) to assure that our results are robust with regard to outliers. ${ }^{15}$ The sample for the further analysis consists of 22,015 observations.

We are primarily interested in the gender congruence between supervisor and employee, i.e. we investigate if the behavior of male and female supervisors is different towards female and male employees. Table 2 involves a contingency table of average fixed effects by gender of the employee and the supervisor. The average fixed effect for female supervisors is uniformly higher than for male supervisors. The average fixed effect for female employees is higher than for male employees, i.e. ceteris paribus supervisors assign a larger number of training days to female employees than to male employees.

Table 2: Contingency table of duration fixed effects

\begin{tabular}{llc}
\hline fixed effects & \multicolumn{2}{c}{ employees } \\
supervisor & males & females \\
\hline male & 2.13 & 2.17 \\
female & 2.17 & 2.26 \\
\hline
\end{tabular}

Now, we perform a multivariate analysis. Table 3 displays the results of a linear regression of the fixed effects on the type of fixed effect (male or female employees) and on the characteristics of the supervisor based on supervisor-employee matches. As we are primarily interested in the relationship between the gender of the supervisor and gender of the employees, we include a variable for the gender of the supervisor, a dummy for a fixed effect for female employees fe_fem (reference are the fixed effects for males), and an interaction term, which is one if the supervisor is female and the fixed effect is for female employees $f e_{-} f e m \times b_{-} f e m$.

\footnotetext{
${ }^{15}$ This eliminates 452 female and 458 male observations from the sample.
} 
Table 3: Regression of fixed effects on gender of employee and supervisor characteristics

\begin{tabular}{lcc}
\hline variables & coefficient & (std. error) \\
\hline gender employee & & \\
fe_fem & 0.020 & $(0.029)$ \\
fe_fem $\times$ b_fem & 0.077 & $(0.059)$ \\
supervisor characteristics & & \\
female & -0.104 & $(0.060)$ \\
dur. training & 0.112 & $(0.005)$ \\
voc. degree & 0.066 & $(0.121)$ \\
univ. degree & 0.082 & $(0.118)$ \\
wage (in 1,000 Euro) & -0.010 & $(0.001)$ \\
tenure & 0.026 & $(0.003)$ \\
full-time & -0.465 & $(0.096)$ \\
corporate title & 0.658 & $(0.066)$ \\
missing dummies & \multicolumn{2}{c}{ yes } \\
year dummies & \multicolumn{2}{c}{ yes } \\
constant & 1.581 & $(0.137)$ \\
\hline$N$ & \multicolumn{2}{c}{22,015} \\
\hline
\end{tabular}

The regression results show that all three gender effects are basically insignificant (the effect for female supervisors is significant at the $10 \%$ level). Thus, supervisor fixed effects do neither depend upon the gender of the employee nor upon the gender congruence between supervisor and employee. A closer look at the other characteristics reveals that especially the training duration of the supervisor influences the size of the fixed effects and, thus, the duration of training of the employees. Supervisors assign more training if their own training duration is longer. Other supervisor characteristics such as wage, tenure, full-time, and coporate title prove significant as well.

For our decomposition analysis, we attribute the supervisor fixed effect to the age-specific characteristics effect assuming that the supervisor is part of the "job environment" of a worker. The resulting age profiles are displayed in Figure 6. The decomposition of the training duration is based on the sample of observations for which we have information on the supervisor. ${ }^{16}$ The profiles of the decomposed effects reveals that the characteristics and the coefficients effect are more pronounced compared to the estimation without fixed effects. These changes are mainly due to a change in the estimates for males in the

\footnotetext{
${ }^{16}$ As a robustness check, we estimated the fixed effects regression on the full sample, including individual fixed effects for those observations with missing information on the supervisor. The decomposition yields similar results.
} 
Figure 6: Age profile of gender decomposition in training duration (including supervisor fixed effects)

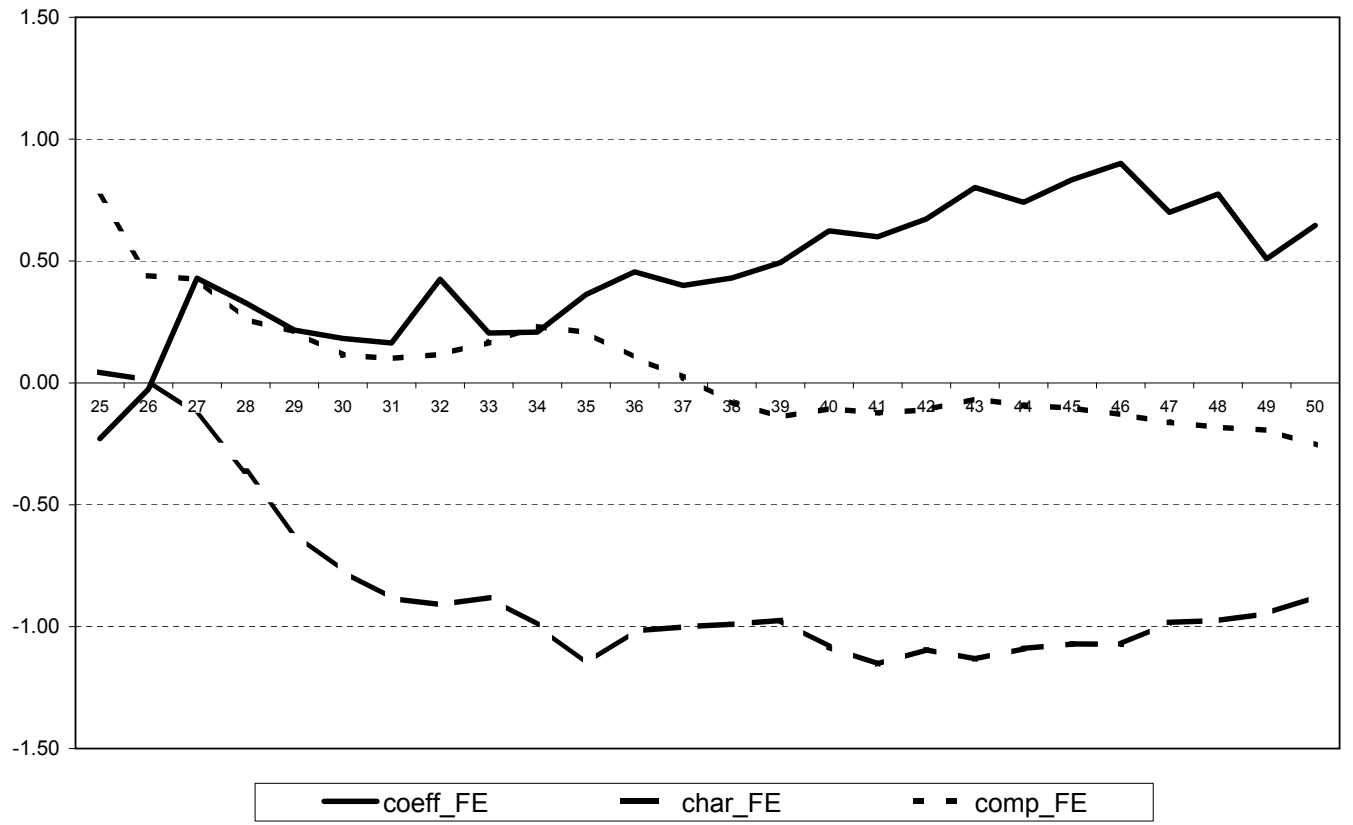

The coefficients effect for the estimation with fixed effects (FE) is indicated by the solid line (coeff_FE), the characteristics effect (char_FE) by the dashed line and the composition effect (comp_FE) by the dotted line.

underlying linear regression leading to different predictions in the counterfactual CharMCoefF-AgeM. However, the shape of the age profile remains unaffected.

To sum up, our results show that the supervisors do not treat male and female employees differently. Supervisors assign more training to all employees if they also participate more in training themselves.

\section{Conclusions}

Company provided training is an important instrument of human resource management to retain a skilled workforce. As technological change constantly outdates acquired skills, training allows to keep employees adequately skilled throughout their professional careers. Based on personnel records of a large company, this paper shows that there exist substantial gender differences in training behavior and that training participation and duration differ by age. We explore in detail the differences in training behavior throughout professional life and consider the impact of parental leave and the influence of supervisors on gender differences.

Our results show that a simple Blinder-Oaxaca decomposition at the mean misses the dynamics in training participation throughout a professional career. The gender training 
gap is not constant throughout the professional life. The average gender gap in training duration is 0.38 days per year. Being close to zero at age 25, the gap evolves during the fist 10 years and peaks at age 35 with females having a 0.75 days shorter training duration per year. This divergence in training behavior can mainly be attributed to differences in characteristics. The difference in individual and job characteristics (such as wage, working time, or hierarchical status) between females and males grows considerably during the first ten years of their professional career. This development is reflected in training duration. After age 35, the gap closes to 0.2 days per year at age 50. The reasons for this are twofold. There is, first, a stabilization in the characteristics effect, i.e. males and females do not further diverge in terms of individual and job characteristics. and, second, a positive coefficients effect, which narrows the gap caused by the characteristics effect.

Female training investments are lower and seem to take place at a higher age. As most of the difference in the age profiles evolves between ages 25 and 40, a potential explanation may be a catching-up process of females after parental leave. Excluding individuals on parental leave reduces the size of the gap and the importance of the characteristics effect but leaves the shape of the age profile unaffected. Although fertility seems to be responsible for diverging careers between males and females, we cannot find evidence for catching-up effects. We investigate whether the overall lower training of females could be due to a different assignment of training by the supervisor according to gender. The multivariate analysis of the supervisor fixed effects for males and females shows that gender congruence of employee and supervisor, i.e. that the supervisor is of the same gender than the employee, does not explain gender differences in training. One strong predictor for both genders is duration of training of the supervisors. Supervisors assign more training to all employees if they also participate more themselves. Supervisor training could be a proxy for the unobserved training needs in a job environment. The decomposition of the training gap shows that attributing the supervisor fixed effects to the characteristics effect adds to the negative characteristics effect.

The results show that males and females participate differently in company provided training. Moreover, the extent of the training gap depends on age, and the training participation is influenced by the training behavior of the supervisor. If a company wants females to work more and both genders to work longer, it needs to adjust training mechanisms to individual demand. Considering the dynamics in training behavior may help improve the employability of both male and female workers. 


\section{References}

Altonji, J. G. \& Spletzer, J. R. (1991), 'Worker Characteristics, Job Characteristics, and the Receipt of On-the-Job Training', Industrial and Labor Relations Review 45(1), 5879 .

Arulampalam, W., Booth, A. L. \& Bryan, M. L. (2004), 'Training in Europe', Journal of the European Economic Association 2(2-3), 346-360.

Barbe, P. \& Bertail, P. (1995), The Weighted Bootstrap, Springer, New York.

Barron, J. M., Black, D. \& Loewenstein, M. (1993), 'Gender Differences in Training, Capital, and Wages', Journal of Human Resources 28(2), 343-363.

Bartel, A., Ichniowski, C. \& Shaw, K. (2004), "Using "Insider Econometrics" to Study Productivity', The American Economic Review 94(2), 217-223.

Bartel, A. P. (1995), 'Training, Wage Growth, and Job Performance: Evidence from a Company Database', Journal of Labor Economics 13(3), 401-425.

Bassanini, A., Booth, A., Brunello, G., De Paola, M. \& Leuven, E. (2007), Workplace Training in Europe, in G. Brunello, P. Garibaldi \& E. Wasmer, eds, 'Education and Training in Europe', Oxford University Press, Oxford.

Becker, G. S. (1964), Human Capital: A Theoretical and Empirical Analysis with Special Reference to Education, Columbia University Press, New York.

Bishop, J. (1996), 'What We Know About Employer-Provided Training: A Review of Literature', CAHRS Working Paper Series, Paper 180.

Blinder, A. S. (1973), 'Wage Discrimination: Reduced Form and Structural Variables', Journal of Human Resources 8(4), 436-455.

Borghans, L., Weel, B. \& Weinberg, B. (2004), 'People People', Unpublished Discussion Paper, Maastricht University and Ohio State University, Comlumbus $\mathrm{OH}$.

Cameron, A., Gelbach, J. \& Miller, D. (2008), 'Bootstrap-based Improvements for Inference with Clustered Errors', The Review of Economics and Statistics 90(3), 414-427.

Cardoso, A. \& Winter-Ebmer, R. (2010), 'Female-led Firms and Gender Wage Policies', Industrial and Labor Relations Review 64(1), 143-162.

Evertsson, M. (2004), 'Formal On-the-Job Training: A Gender-Typed Experience and Wage-Related Advantage?', European Sociological Review 20(1), 79-94. 
Fairlie, R. (2005), 'An Extension of the Blinder-Oaxaca Decomposition Technique to Logit and Probit Models', Journal of Economic and Social Measurement 30(4), 305-316.

Frazis, H. \& Loewenstein, M. A. (2006), 'On-the-Job-Training', Foundations and Trends in Microeconomics 2(5), 1-82.

Graves, L. \& Powell, G. (1995), 'The Effect of Sex Similarity on Recruiters' Evaluations of Actual Applicants: A Test of the Similarity-Attraction Paradigm', Personnel Psychology 48(1), 85-98.

Green, F. \& Zanchi, L. (1997), 'Trends in the Training of Male and Female Workers in the United Kingdom', British Journal of Industrial Relations 35(4), 635-644.

Grund, C. \& Martin, J. (2010), 'Determinants of Further Training: Evidence for Germany', IZA Discussion Paper 5315.

Ichniowski, C. \& Shaw, K. (2003), 'Beyond Incentive pay: Insiders' Estimates of the Value of Complementary Human Resource Management Practices', Journal of Economic Perspectives $\mathbf{1 7}(1)$, 155-180.

Krueger, A. \& Rouse, C. (1998), 'The Effect of Workplace Education on Earnings, Turnover, and Job Performance', Journal of Labor Economics 16(1), 61-94.

Lynch, L. M. (1992), 'Private Sector Training and the Earnings of Young Workers', The American Economic Review 82(1), 299-312.

Melero, E. (2004), 'Sex Differences in Managerial Style: From Individual Leadership to Organisational Labour Relationships', IZA Discussion Paper 1387.

Mincer, J. \& Polachek, S. (1974), 'Family Investments in Human Capital: Earnings of Women', Journal of Political Economy 72(Part 2), S76-S108.

Oaxaca, R. (1973), 'Male-Female Wage Differentials in Urban Labor Markets', International Economic Review 14, 693-709.

OECD (1999), 'Employment Outlook', Chapter 3: Training of adult workers in OECD countries: Measurement and Analysis, Paris pp. 134-175.

OECD (2003), 'Employment Outlook', Chapter 5: Upgrading Workers' Skills and Competencies, Paris pp. 237-296.

O'Halloran, P. L. (2008), 'Gender Differences in Formal on-the-Job Training: Incidence, Duration, and Intensity', LABOUR: Review of Labour Economics $\&$ Industrial Relations 22(4), 629-659. 
Puhani, P. \& Sonderhof, K. (2011), 'The Effects of a Parental Leave Extension on Training for Young Women', Journal of Population Economics 24(2), 731-760.

Rothstein, D. (1997), Early career supervisor gender and the labor market outcomes of young workers, in F. Blau \& R. Ehrenberg, eds, 'Gender and Family Issues in the Workplace', Russell Sage Foundation, New York, pp. 210-255.

Royalty, A. B. (1996), 'The Effects of Job Turnover on the Training of Men and Women', Industrial and Labor Relations Review 49(3), 506-521.

Shakeshaft, C., Irene Nowell, I. \& Perry, A. (1991), 'Gender and Supervision', Theory into Practice 30(2), 134-139.

Simpson, P. \& Stroh, L. (2002), 'Revisiting Gender Variation in Training', Feminist Economics $\mathbf{8}(3), 21-53$.

Veum, J. R. (1995), 'Sources of Training and Their Impact on Wages', Industrial and Labor Relations Review 48(4), 812-826.

Veum, J. R. (1996), 'Gender and Race Differences in Company Training', Industrial Relations 35(1), 32-44.

Xiangmin, L. \& Batt, R. (2007), 'Economic Pay-Offs to Informal Training: Evidence from Routine Service Work', Industrial and Labor Relations Review 61(1), 75-89. 


\section{A Appendix}

\section{A.1 Figures}

Figure A.1: Wages of males and females by age

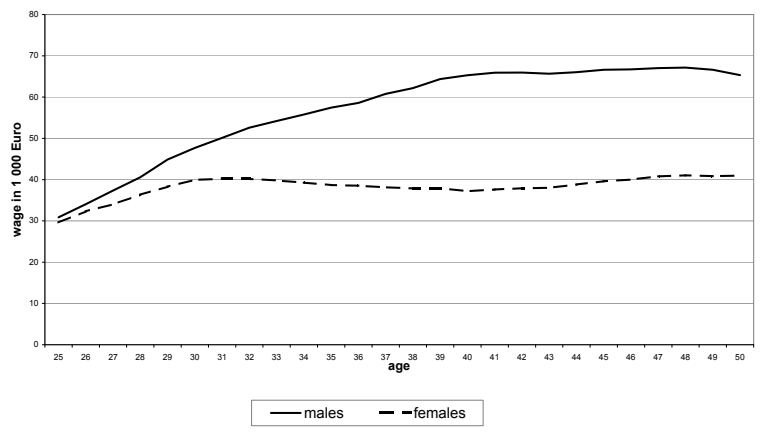

Figure A.2: Working time (in full-time equivalents) of males and females by age

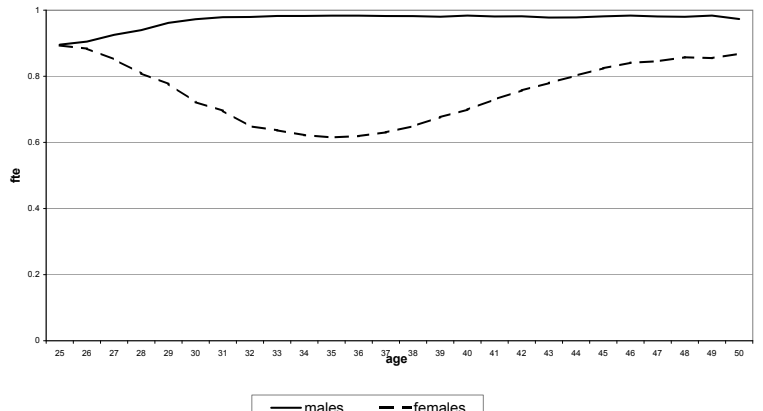

Figure A.3: Share of females among all employees and among supervisors by age

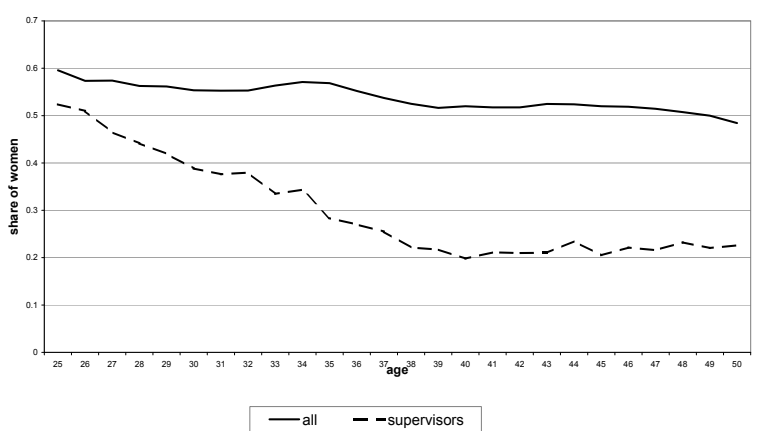




\section{A.2 Tables}

Table A.1: Gender distribution along the age profile (in $\%)$

\begin{tabular}{|c|c|c|}
\hline age & males & females \\
\hline 25 & 40.4 & 59.6 \\
\hline 26 & 42.7 & 57.3 \\
\hline 27 & 42.6 & 57.4 \\
\hline 28 & 43.7 & 56.3 \\
\hline 29 & 43.9 & 56.2 \\
\hline 30 & 44.7 & 55.4 \\
\hline 31 & 44.7 & 55.3 \\
\hline 32 & 44.7 & 55.3 \\
\hline 33 & 43.6 & 56.4 \\
\hline 34 & 42.9 & 57.1 \\
\hline 35 & 43.1 & 56.9 \\
\hline 36 & 44.8 & 55.2 \\
\hline 37 & 46.3 & 53.7 \\
\hline 38 & 47.5 & 52.5 \\
\hline 39 & 48.4 & 51.6 \\
\hline 40 & 48.0 & 52.0 \\
\hline 41 & 48.3 & 51.7 \\
\hline 42 & 48.3 & 51.7 \\
\hline 43 & 47.5 & 52.5 \\
\hline 44 & 47.6 & 52.4 \\
\hline 45 & 48.0 & 52.0 \\
\hline 46 & 48.1 & 51.9 \\
\hline 47 & 48.6 & 51.4 \\
\hline 48 & 49.3 & 50.7 \\
\hline 49 & 50.0 & 50.0 \\
\hline 50 & 51.6 & 48.4 \\
\hline total & 46.2 & 53.8 \\
\hline
\end{tabular}


Table A.2: Regression of training incidence on age, separate for males and females

\begin{tabular}{|c|c|c|c|c|}
\hline \multirow[b]{2}{*}{ variable } & \multicolumn{2}{|c|}{ men } & \multicolumn{2}{|c|}{ females } \\
\hline & coefficient & std. err. & coefficient & std. err. \\
\hline d_age26 & 0.327 & 0.217 & 0.241 & 0.187 \\
\hline d_age27 & 0.107 & 0.217 & 0.076 & 0.187 \\
\hline d_age28 & 0.035 & 0.219 & -0.061 & 0.188 \\
\hline d_age29 & -0.050 & 0.220 & -0.191 & 0.190 \\
\hline d_age30 & -0.100 & 0.223 & -0.353 & 0.193 \\
\hline d_age31 & 0.217 & 0.229 & 0.254 & 0.192 \\
\hline d_age32 & 0.113 & 0.231 & 0.179 & 0.193 \\
\hline d_age33 & 0.111 & 0.232 & 0.086 & 0.194 \\
\hline d_age34 & 0.035 & 0.234 & -0.018 & 0.195 \\
\hline d_age35 & 0.015 & 0.237 & -0.010 & 0.198 \\
\hline d_age36 & 0.109 & 0.237 & 0.172 & 0.199 \\
\hline d_age37 & 0.057 & 0.238 & 0.091 & 0.199 \\
\hline d_age38 & 0.029 & 0.240 & 0.064 & 0.201 \\
\hline d_age39 & -0.013 & 0.243 & 0.001 & 0.203 \\
\hline d_age40 & -0.047 & 0.247 & 0.024 & 0.206 \\
\hline d_age41 & -0.139 & 0.249 & -0.124 & 0.206 \\
\hline d_age 42 & -0.200 & 0.250 & -0.174 & 0.207 \\
\hline d_age43 & -0.180 & 0.253 & -0.211 & 0.208 \\
\hline d_age44 & -0.202 & 0.258 & -0.219 & 0.212 \\
\hline d_age45 & -0.206 & 0.264 & -0.213 & 0.217 \\
\hline d_age 46 & -0.457 & 0.266 & -0.487 & 0.215 \\
\hline d_age47 & -0.452 & 0.268 & -0.561 & 0.216 \\
\hline d_age48 & -0.444 & 0.271 & -0.544 & 0.219 \\
\hline d_age49 & -0.411 & 0.277 & -0.559 & 0.224 \\
\hline d_age50 & -0.404 & 0.285 & -0.613 & 0.232 \\
\hline dberuf & -0.471 & 0.248 & -0.792 & 0.165 \\
\hline dstudium & -0.834 & 0.536 & -1.001 & 0.526 \\
\hline gehalt1000 & -0.007 & 0.005 & -0.013 & 0.005 \\
\hline tenure & 0.230 & 0.022 & 0.222 & 0.017 \\
\hline dfte & -3.640 & 1.005 & -2.522 & 1.583 \\
\hline dtitel & -1.428 & 0.108 & -0.195 & 0.094 \\
\hline supervisor & 0.502 & 2.905 & -2.426 & 1.191 \\
\hline interaction terms & \multicolumn{2}{|c|}{ yes } & \multicolumn{2}{|c|}{ yes } \\
\hline missing dummies & \multicolumn{2}{|c|}{ yes } & \multicolumn{2}{|c|}{ yes } \\
\hline year dummies & \multicolumn{2}{|c|}{ yes } & \multicolumn{2}{|c|}{ yes } \\
\hline interaction age year & \multicolumn{2}{|c|}{ yes } & \multicolumn{2}{|c|}{ yes } \\
\hline _cons & -0.159 & 0.231 & -0.209 & 0.189 \\
\hline $\mathrm{N}$ & \multicolumn{2}{|c|}{47,096} & \multicolumn{2}{|c|}{54,793} \\
\hline
\end{tabular}

Standard Errors are clustered at the individual level. 
Table A.3: Regression of number of training days on age, separate for males and females

\begin{tabular}{|c|c|c|c|c|}
\hline variable & $\begin{array}{r}\text { me } \\
\text { coefficient }\end{array}$ & $\begin{array}{l}\mathbf{n} \\
\text { std. } \\
\text { err. }\end{array}$ & $\begin{array}{r}\text { fema } \\
\text { coefficient }\end{array}$ & $\begin{array}{l}\text { les } \\
\text { std. } \\
\text { err. }\end{array}$ \\
\hline d_age26 & -0.342 & 0.395 & -0.323 & 0.294 \\
\hline d_age27 & -0.818 & 0.406 & -0.466 & 0.300 \\
\hline d_age28 & -0.904 & 0.413 & -0.827 & 0.294 \\
\hline d_age29 & -1.006 & 0.419 & -1.182 & 0.296 \\
\hline d_age30 & -1.135 & 0.421 & -1.463 & 0.305 \\
\hline d_age31 & -0.878 & 0.458 & -0.721 & 0.312 \\
\hline d_age32 & -1.198 & 0.461 & -0.734 & 0.312 \\
\hline d_age33 & -1.370 & 0.464 & -1.082 & 0.318 \\
\hline d_age34 & -1.413 & 0.471 & -1.233 & 0.324 \\
\hline d_age35 & -1.561 & 0.476 & -1.325 & 0.331 \\
\hline d_age36 & -1.606 & 0.472 & -0.871 & 0.333 \\
\hline d_age37 & -1.749 & 0.476 & -1.110 & 0.335 \\
\hline d_age38 & -1.858 & 0.480 & -1.107 & 0.339 \\
\hline d_age39 & -2.047 & 0.485 & -1.235 & 0.344 \\
\hline d_age40 & -2.150 & 0.492 & -1.270 & 0.354 \\
\hline d_age41 & -1.805 & 0.492 & -1.815 & 0.353 \\
\hline d_age42 & -1.971 & 0.495 & -1.871 & 0.355 \\
\hline d_age43 & -2.119 & 0.500 & -1.923 & 0.358 \\
\hline d_age44 & -2.211 & 0.509 & -2.004 & 0.365 \\
\hline d_age45 & -2.293 & 0.522 & -1.951 & 0.374 \\
\hline d_age46 & -2.655 & 0.513 & -2.358 & $0 . .37$ \\
\hline d_age47 & -2.667 & 0.516 & -2.449 & 0.378 \\
\hline d_age48 & -2.844 & 0.521 & -2.537 & 0.383 \\
\hline d_age49 & -2.784 & 0.532 & -2.634 & 0.392 \\
\hline d_age50 & -3.039 & 0.545 & -2.683 & 0.409 \\
\hline dberuf & 0.262 & 0.514 & -1.350 & 0.339 \\
\hline dstudium & 1.279 & 1.235 & 0.050 & 1.243 \\
\hline gehalt1000 & -0.039 & 0.010 & -0.024 & 0.009 \\
\hline tenure & 0.275 & 0.045 & 0.335 & 0.033 \\
\hline dfte & -9.194 & 1.803 & -5.149 & 1.059 \\
\hline dtitel & -2.691 & 0.238 & -0.401 & 0.195 \\
\hline supervisor & 5.322 & 2.208 & -0.811 & 3.072 \\
\hline interaction terms & \multicolumn{2}{|c|}{ yes } & \multicolumn{2}{|c|}{ yes } \\
\hline missing dummies & \multicolumn{2}{|c|}{ yes } & \multicolumn{2}{|c|}{ yes } \\
\hline year dummies & \multicolumn{2}{|c|}{ yes } & \multicolumn{2}{|c|}{ yes } \\
\hline interaction age year & \multicolumn{2}{|c|}{ yes } & \multicolumn{2}{|c|}{ yes } \\
\hline _cons & 3.820 & 0.466 & 2.644 & 0.325 \\
\hline $\mathrm{N}$ & \multicolumn{2}{|c|}{47,096} & \multicolumn{2}{|c|}{54,793} \\
\hline
\end{tabular}

Standard Errors are clustered at the individual level. 
Table A.4: Regression of training incidence and duration on age profile and gender

\begin{tabular}{|c|c|c|c|c|}
\hline \multirow[b]{2}{*}{ variable } & \multicolumn{2}{|c|}{ training participation (Probit) } & \multicolumn{2}{|c|}{ training days (OLS) } \\
\hline & coefficient & std. err. & coefficient & std. err. \\
\hline d_age 26 & 0.229 & 0.145 & -0.521 & 0.269 \\
\hline d_age27 & 0.037 & 0.145 & -0.803 & 0.273 \\
\hline d_age28 & -0.074 & 0.146 & -1.040 & 0.272 \\
\hline d_age29 & -0.185 & 0.147 & -1.288 & 0.277 \\
\hline d_age30 & -0.299 & 0.149 & -1.495 & 0.279 \\
\hline d_age31 & 0.089 & 0.150 & -1.103 & 0.289 \\
\hline d_age32 & -0.001 & 0.151 & -1.264 & 0.290 \\
\hline d_age33 & -0.050 & 0.152 & -1.537 & 0.294 \\
\hline d_age34 & -0.141 & 0.153 & -1.646 & 0.298 \\
\hline d_age35 & -0.144 & 0.155 & -1.765 & 0.302 \\
\hline d_age36 & -0.012 & 0.155 & -1.602 & 0.298 \\
\hline d_age37 & -0.076 & 0.155 & -1.800 & 0.300 \\
\hline d_age38 & -0.100 & 0.156 & -1.846 & 0.302 \\
\hline d_age39 & -0.151 & 0.157 & -2.003 & 0.305 \\
\hline d_age40 & -0.153 & 0.159 & -2.075 & 0.309 \\
\hline d_age41 & -0.329 & 0.161 & -2.179 & 0.313 \\
\hline d_age 42 & -0.380 & 0.162 & -2.283 & 0.314 \\
\hline d_age43 & -0.386 & 0.163 & -2.377 & 0.316 \\
\hline d_age44 & -0.391 & 0.165 & -2.450 & 0.320 \\
\hline d_age45 & -0.385 & 0.168 & -2.455 & 0.326 \\
\hline d_age46 & -0.672 & 0.172 & -2.959 & 0.325 \\
\hline d_age47 & -0.698 & 0.173 & -3.001 & 0.325 \\
\hline d_age48 & -0.681 & 0.175 & -3.129 & 0.327 \\
\hline d_age49 & -0.666 & 0.178 & -3.141 & 0.332 \\
\hline d_age50 & -0.690 & 0.183 & -3.293 & 0.339 \\
\hline dfemale & -0.020 & 0.065 & -0.510 & 0.195 \\
\hline fage 2630 & -0.029 & 0.069 & 0.485 & 0.200 \\
\hline fage 3135 & -0.058 & 0.070 & 0.433 & 0.204 \\
\hline fage 3640 & -0.056 & 0.070 & 0.543 & 0.202 \\
\hline fage 4145 & 0.069 & 0.071 & 0.603 & 0.203 \\
\hline fage 4650 & 0.117 & 0.073 & 0.749 & 0.203 \\
\hline dberuf & -0.780 & 0.136 & -1.016 & 0.280 \\
\hline dstudium & -0.837 & 0.368 & 0.267 & 0.867 \\
\hline gehalt1000 & -0.014 & 0.004 & -0.034 & 0.007 \\
\hline tenure & 0.234 & 0.014 & 0.319 & 0.027 \\
\hline dfte & -2.567 & 0.475 & -4.436 & 0.864 \\
\hline dtitel & -0.751 & 0.070 & -1.559 & 0.148 \\
\hline supervisor & -0.324 & 0.717 & 3.540 & 1.749 \\
\hline interaction terms & & $y$ & & \\
\hline missing dummies & & $y$ & & \\
\hline year dummies & & $y$ & & \\
\hline interaction age year & & & & \\
\hline constant & -0.001 & 0.148 & 3.644 & 0.293 \\
\hline $\mathrm{N}$ & & 101 & & \\
\hline
\end{tabular}

Standard Errors are clustered at the individual level. 
Table A.5: Results of the regression decomposition terms of training participation on the age profile

\begin{tabular}{|c|c|c|c|c|c|c|}
\hline & \multicolumn{2}{|c|}{ coefficients effect } & \multicolumn{2}{|c|}{ characteristics effect } & \multicolumn{2}{|c|}{ composition effect } \\
\hline & coefficient & (std. err.) & coefficient & (std. err.) & coefficient & (std. err.) \\
\hline d_age 25 & 0.002 & $(0.019)$ & 0.058 & $(0.013)$ & 0.168 & $(0.035)$ \\
\hline d_age26 & -0.013 & $(0.018)$ & 0.046 & $(0.010)$ & 0.098 & $(0.030)$ \\
\hline d_age27 & 0.016 & $(0.017)$ & 0.016 & $(0.009)$ & 0.095 & $(0.028)$ \\
\hline d_age28 & 0.008 & $(0.016)$ & -0.021 & $(0.009)$ & 0.060 & $(0.022)$ \\
\hline d_age29 & 0.007 & $(0.016)$ & -0.056 & $(0.009)$ & 0.056 & $(0.021)$ \\
\hline d_age30 & -0.015 & $(0.015)$ & -0.082 & $(0.010)$ & 0.033 & $(0.018)$ \\
\hline d_age31 & -0.012 & $(0.016)$ & -0.090 & $(0.009)$ & 0.030 & $(0.017)$ \\
\hline d_age32 & 0.004 & $(0.015)$ & -0.093 & $(0.008)$ & 0.030 & $(0.016)$ \\
\hline d_age33 & -0.020 & $(0.015)$ & -0.101 & $(0.009)$ & 0.051 & $(0.016)$ \\
\hline d_age34 & -0.022 & $(0.016)$ & -0.099 & $(0.009)$ & 0.065 & $(0.016)$ \\
\hline d_age35 & -0.006 & $(0.015)$ & -0.109 & $(0.010)$ & 0.062 & $(0.016)$ \\
\hline d_age36 & -0.032 & $(0.015)$ & -0.077 & $(0.009)$ & 0.028 & $(0.015)$ \\
\hline d_age37 & -0.035 & $(0.014)$ & -0.061 & $(0.008)$ & -0.001 & $(0.013)$ \\
\hline d_age38 & -0.026 & $(0.014)$ & -0.072 & $(0.008)$ & -0.024 & $(0.013)$ \\
\hline d_age39 & -0.024 & $(0.015)$ & -0.067 & $(0.009)$ & -0.040 & $(0.013)$ \\
\hline d_age40 & 0.005 & $(0.016)$ & -0.065 & $(0.010)$ & -0.037 & $(0.014)$ \\
\hline d_age41 & 0.025 & $(0.016)$ & -0.073 & $(0.012)$ & -0.043 & $(0.014)$ \\
\hline d_age 42 & 0.039 & $(0.015)$ & -0.064 & $(0.010)$ & -0.044 & $(0.014)$ \\
\hline d_age 43 & 0.028 & $(0.016)$ & -0.064 & $(0.010)$ & -0.028 & $(0.015)$ \\
\hline d_age44 & 0.041 & $(0.017)$ & -0.065 & $(0.011)$ & -0.030 & $(0.017)$ \\
\hline d_age 45 & 0.053 & $(0.018)$ & -0.066 & $(0.012)$ & -0.040 & $(0.017)$ \\
\hline d_age46 & 0.062 & $(0.019)$ & -0.090 & $(0.012)$ & -0.041 & $(0.018)$ \\
\hline d_age 47 & 0.043 & $(0.020)$ & -0.090 & $(0.012)$ & -0.048 & $(0.017)$ \\
\hline d_age 48 & 0.056 & $(0.020)$ & -0.090 & $(0.012)$ & -0.062 & $(0.018)$ \\
\hline d_age 49 & 0.048 & $(0.021)$ & -0.083 & $(0.013)$ & -0.075 & $(0.017)$ \\
\hline d_age50 & 0.038 & $(0.021)$ & -0.081 & $(0.013)$ & -0.097 & $(0.016)$ \\
\hline
\end{tabular}

Standard Errors (in brackets) are calculated using a weighted bootstrap procedure with 1,000 replications. The weights are drawn from a uniform distribution on the interval $[0,2]$ with mean one and variance of $1 / 3$. The obtained variances are finally multiplied by factor three.n The same weight is assigned to each individual over time so that automatically clustered standard errors at the individual level are produced. 
Table A.6: Results of the regression decomposition terms of training duration on the age profile

\begin{tabular}{|c|c|c|c|c|c|c|}
\hline \multirow{3}{*}{ d_age25 } & \multirow{2}{*}{\multicolumn{2}{|c|}{$\begin{array}{l}\text { coefficients effect } \\
\text { coefficient } \quad(\text { std. err. })\end{array}$}} & \multicolumn{2}{|c|}{ characteristics effect } & \multicolumn{2}{|c|}{ composition effect } \\
\hline & & & coefficient & (std. err.) & coefficient & (std. err.) \\
\hline & -0.487 & $(0.191)$ & 0.280 & $(0.069)$ & 0.772 & $(0.157)$ \\
\hline d_age26 & -0.152 & $(0.156)$ & 0.189 & $(0.059)$ & 0.441 & $(0.127)$ \\
\hline d_age27 & 0.306 & $(0.150)$ & 0.002 & $(0.054)$ & 0.452 & $(0.121)$ \\
\hline d_age28 & 0.154 & $(0.134)$ & -0.194 & $(0.054)$ & 0.272 & $(0.099)$ \\
\hline d_age29 & 0.062 & $(0.123)$ & -0.417 & $(0.052)$ & 0.239 & $(0.085)$ \\
\hline d_age30 & 0.029 & $(0.122)$ & -0.583 & $(0.052)$ & 0.139 & $(0.069)$ \\
\hline d_age31 & -0.059 & $(0.108)$ & -0.668 & $(0.042)$ & 0.116 & $(0.061)$ \\
\hline d_age32 & 0.284 & $(0.114)$ & -0.728 & $(0.042)$ & 0.123 & $(0.062)$ \\
\hline d_age33 & 0.133 & $(0.095)$ & -0.770 & $(0.041)$ & 0.184 & $(0.053)$ \\
\hline d_age34 & 0.040 & $(0.102)$ & -0.790 & $(0.042)$ & 0.233 & $(0.052)$ \\
\hline d_age35 & 0.095 & $(0.100)$ & -0.855 & $(0.046)$ & 0.215 & $(0.049)$ \\
\hline d_age36 & 0.189 & $(0.091)$ & -0.724 & $(0.043)$ & 0.098 & $(0.044)$ \\
\hline d_age 37 & 0.091 & $(0.089)$ & -0.680 & $(0.041)$ & -0.002 & $(0.037)$ \\
\hline d_age38 & 0.181 & $(0.091)$ & -0.727 & $(0.042)$ & -0.080 & $(0.038)$ \\
\hline d_age39 & 0.231 & $(0.097)$ & -0.698 & $(0.045)$ & -0.132 & $(0.038)$ \\
\hline d_age40 & 0.268 & $(0.096)$ & -0.702 & $(0.053)$ & -0.115 & $(0.040)$ \\
\hline d_age41 & 0.285 & $(0.103)$ & -0.808 & $(0.062)$ & -0.127 & $(0.039)$ \\
\hline d_age 42 & 0.357 & $(0.102)$ & -0.745 & $(0.056)$ & -0.132 & $(0.039)$ \\
\hline d_age 43 & 0.414 & $(0.100)$ & -0.724 & $(0.053)$ & -0.085 & $(0.043)$ \\
\hline d_age44 & 0.377 & $(0.102)$ & -0.703 & $(0.054)$ & -0.090 & $(0.048)$ \\
\hline d_age 45 & 0.473 & $(0.116)$ & -0.687 & $(0.061)$ & -0.121 & $(0.052)$ \\
\hline d_age46 & 0.584 & $(0.117)$ & -0.713 & $(0.077)$ & -0.122 & $(0.051)$ \\
\hline d_age47 & 0.446 & $(0.118)$ & -0.705 & $(0.074)$ & -0.141 & $(0.046)$ \\
\hline d_age48 & 0.483 & $(0.111)$ & -0.679 & $(0.074)$ & -0.169 & $(0.046)$ \\
\hline d_age49 & 0.248 & $(0.114)$ & -0.653 & $(0.077)$ & -0.188 & $(0.044)$ \\
\hline d_age50 & 0.381 & $(0.119)$ & -0.614 & $(0.079)$ & -0.241 & $(0.040)$ \\
\hline $\mathrm{N}$ & & & 10 & 889 & & \\
\hline
\end{tabular}

Standard Errors (in brackets) are calculated by bootstrapping using a normal approximation with 1,000 replications. 